\title{
Validation of a Method Scope Extension for the Analysis of POPs in Soil and Verification in Organic and Conventional Farms of the Canary Islands
}

\author{
Andrea Acosta-Dacal 1,+(D), Cristian Rial-Berriel 1,+(iD), Ricardo Díaz-Díaz ${ }^{2}$, María del Mar Bernal-Suárez ${ }^{2}$,

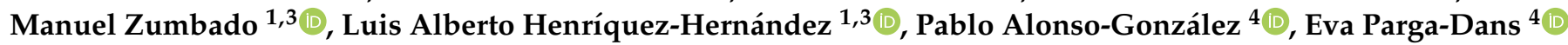 \\ and Octavio P. Luzardo $1,3, *$
}

1 Toxicology Unit, Research Institute of Biomedical and Health Sciences (IUIBS), Universidad de Las Palmas de Gran Canaria, Paseo Blas Cabrera s/n, 35016 Las Palmas, Spain; andrea.acosta@ulpgc.es (A.A.-D.); cristian.rial@ulpgc.es (C.R.-B.); manuel.zumbado@ulpgc.es (M.Z.); luis.henriquez@ulpgc.es (L.A.H.-H.)

2 Department of Environmental Analysis, Technological Institute of the Canary Islands, C/ Los Cactus no 68, Polígono Industrial de Arinaga, Agüimes, 35118 Las Palmas, Spain; rdiaz@itccanarias.org (R.D.-D.); mbernal@itccanarias.org (M.d.M.B.-S.)

3 Spanish Biomedical Research Center in Physiopathology of Obesity and Nutrition (CIBERObn), Instituto de Salud Carlos III, 28029 Madrid, Spain

4 IPNA-CSIC, Av. Astrofisico Francisco Sánchez, 3, 38206 San Cristóbal de La Laguna, Spain; pabloag10@hotmail.com (P.A.-G.); eva.parga.dans@hotmail.com (E.P.-D.)

check for updates

Citation: Acosta-Dacal, A.; Rial-Berriel, C.; Díaz-Díaz, R.; Bernal-Suárez, M.d.M.; Zumbado, M.; Henríquez-Hernández, L.A.; Alonso-González, P.; Parga-Dans, E.; Luzardo, O.P. Validation of a Method Scope Extension for the Analysis of POPs in Soil and Verification in Organic and Conventional Farms of the Canary Islands. Toxics 2021, 9, 101. https://doi.org/10.3390/toxics 9050101

Academic Editor: Magnus Engwall

Received: 7 April 2021

Accepted: 29 April 2021

Published: 2 May 2021

Publisher's Note: MDPI stays neutral with regard to jurisdictional claims in published maps and institutional affiliations.

Copyright: (C) 2021 by the authors. Licensee MDPI, Basel, Switzerland. This article is an open access article distributed under the terms and conditions of the Creative Commons Attribution (CC BY) license (https:/ / creativecommons.org/licenses/by/ $4.0 /)$.
* Correspondence: octavio.perez@ulpgc.es; Tel.: +34-928-451-424

+ Both authors should be considered as first authors since they have contributed equally to this work.
Abstract: Persistent organic pollutants (POPs) are among the most relevant and dangerous contaminants in soil, from where they can be transferred to crops. Additionally, livestock animals may inadvertently consume relatively high amounts of soil attached to the roots of the vegetables while grazing, leading to indirect exposure to humans. Therefore, periodic monitoring of soils is crucial; thus, simple, robust, and powerful methods are needed. In this study, we have tested and validated an easy QuEChERS-based method for the extraction of 49 POPs (8 PBDEs, 12 OCPs, 11 PAHs, and 18 PCBs) in soils and their analysis by GC-MS/MS. The method was validated in terms of linearity, precision, and accuracy, and a matrix effect study was performed. The limits of detection (LOD) were established between 0.048 and $3.125 \mathrm{ng} \mathrm{g}^{-1}$ and the limits of quantification (LOQ) were between 0.5 and $20 \mathrm{ng} \mathrm{g}^{-1}$, except for naphthalene $\left(50 \mathrm{ng} \mathrm{g}^{-1}\right)$. Then, to verify the applicability of the validated method, we applied it to a series of 81 soil samples from farms dedicated to mixed vegetable cultivation and vineyards in the Canary Islands, both from two modes of production (organic vs. conventional) where residues of OCPs, PCBs, and PAHs were found.

Keywords: QuEChERS; organochlorine pesticides; PCBs; PAHs; PBDEs; gas chromatographymass spectrometry

\section{Introduction}

Semi-persistent and persistent organic pollutants (POPs) constitute a large group of compounds that has been widely studied due to their controversial properties. POPs are characterized by their toxicity, resistance to degradation, ability to be transported over long distances, lipophilicity, and tendency to bioaccumulate and biomagnify along the food chain [1]. In this group are compounds of very different nature and usage: industrial applications, i.e., polybrominated diphenyl ethers (PBDEs) and polychlorinated Biphenyls (PCBs); pest control, i.e., organochlorine pesticides (OCPs); or as by-products emitted during the incomplete combustion of organic materials, especially in anthropogenic activities, i.e., polycyclic aromatic hydrocarbons (PAHs) [2,3]. They were used extensively during the 20th century until their restriction, prohibition, or reduction in unintentional 
emissions following the Stockholm Convention based on their mutagenic, carcinogenic, and endocrine-disrupting properties [4]. Although most of these compounds have been banned in the majority of developing countries for more than 40 years [5,6], many of them still pose a threat to the environment, wildlife, and human health due to their historical use and continuing unintentional emissions.

Soil is regarded as the ultimate sink for persistent organic pollutants, from where they can be emitted to the atmosphere, ground or surface water, and biota $[7,8]$. POPs can reach soils not only by historical, direct application of OCPs to the crops [9], but also through atmospheric deposition and volatilization processes $[10,11]$. Thus, even in remote areas where they have never been used, soils can receive inputs of these compounds [11]. The degree to which they are absorbed is influenced by the characteristics of the soil. Clay mineral content, organic matter content, and soil $\mathrm{pH}$ can affect their retention, depending on their chemical properties [12]. Given their lipophilic nature, POPs show a high affinity for soil organic matter [13]. Consequently, a part of their input will not be degraded, nor volatilized, nor leached, and may persist for a long time in this medium [14,15]. Although the interaction between the soil matrix and the POPs is stronger, it does not prevent specific plants such as Cucurbitaceae from taking up a part of them [16]. As a consequence, these compounds can find their way into food and feed, leading to bioaccumulation problems in animals and humans $[17,18]$; thus, biomagnification $[19,20]$.

Humans may be exposed to soil contamination not only indirectly through the ingestion of crops and grazing-animal products, but also by direct contact with soil or even the ingestion of it. The latter might occur through three different pathways: (1) ingestion, (accidental or deliberate, geophagy); (2) inhalation; and (3) dermal absorption or penetration [21]. From these, the ingestion of soil and dust particles may be a potentially important pathway of exposure to environmental pollutants [22]. Accidental ingestion may occur during the consumption of poorly washed fruits and vegetables, through airborne dust, or in hand-to-mouth contact, which is quite common in children [23]. In general, children's ingestion rates are assumed to be higher than in adults, who may also ingest soil during occupational activities [22]. In addition, unintentional ingestion of soil containing POPs by farm animals raised outdoors may be the main cause of contamination of animal products (meat, milk, or eggs). The most recent studies indicate that soil is a real risk matrix in terms of the transfer of POPs into the food chain [24], especially in areas with high levels of contamination.

For all these reasons, it is relevant to have methods that enable the reliable monitoring of POPs in soils, which is essential to determine not only the level of environmental contamination or the efficacy of remediation measures, but also any potential risk to the population [1].

Traditionally, sample preparation methods used for these compounds in the soil matrix were long and laborious, involved several steps, and employed hazardous and polluting reagents and solvents such as the Soxhlet extraction [25,26], or required expensive equipment such as in microwave-assisted extraction (MAE) $[27,28]$ and pressurized liquid extraction (PLE) $[29,30]$. To overcome these disadvantages, some authors have used the original or modified QuEChERS method [31,32]. Introduced by Anastassiades et al. in 2003 for the extraction of pesticides from fruits and vegetables [33], it involves an acetonitrile extraction/partitioning step followed by a dispersive solid phase extraction clean-up step. Since then, it has been used for other matrices and analytes due to the high extraction yields using reduce amounts of samples and organic solvents along with its speed, simplicity, and low cost [34]. Once extracted, given that most of them are non-polar compounds, POPs have been analyzed by gas chromatography (GC) coupled to different detectors, particularly electron capture (ECD) $[27,35]$ and mass spectrometry (MS) [36,37]. Nevertheless, due to their highly sensitivity and selectivity, triple quadrupole mass spectrometry (MS/MS) is an ideal technique for both the screening and quantitative analysis of POPs [38,39].

A QuEChERS-based method for the determination of 218 agricultural pesticides in soil has recently been developed in our laboratory. Based on this methodology, we have 
proposed this scope extension research, with two main objectives: (1) to evaluate and validate a QuEChERS-based and GC-MS/MS method for the quantitative determination of POPs in soils of agricultural origin by GC-MS/MS; and (2) to verify the applicability of this method by analyzing a series of samples of agricultural soils from the Canary Islands, a territory where high levels of POPs have been reported in its population [40-43] and biota [44,45]. With the validated procedure, we were able to analyze 49 compounds, including 8 PBDEs, 12 OCPs, 11 PAHs, and 18 PCBs, accurately and reliably in 81 soil samples belonging to different agricultural plots of the archipelago.

\section{Materials and Methods}

\subsection{Reagents, Standard Stock Solutions and Mixes}

Analytical-grade acetonitrile (ACN), acetone (Ac) and formic acid (FA, $\mathrm{HCOOH})$ were obtained from Honeywell (Morristown, NJ, USA). AOAC method QuEChERS salts were acquired in commercial premixes from Agilent Technologies (Palo Alto, CA, USA). All the standards of the selected POPs were purchased from CPA Chem (Stara Zagora, Bulgaria). To ensure stability, these compounds were supplied in 5 mixes at $100 \mu \mathrm{g} \mathrm{mL}^{-1}$ each: one for OCPs (in Ac), one for PAHs (in dichloromethane), one for PBDEs (in iso-octane), and two for PCBs (in iso-octane). PCB 200 was used as procedural internal standard (P-IS) and was acquired form Dr. Ehrenstorfer (Augsburg, Germany) at $10 \mathrm{ng} \mu \mathrm{L}^{-1}$. An intermediate solution was prepared by mixing all the commercial standard stocks $\left(20 \mu \mathrm{g} \mathrm{mL}^{-1}\right.$ each compound), and from this, a working solution at $1 \mu \mathrm{g} \mathrm{mL} \mathrm{m}^{-1}$ in Ac was prepared. Likewise, a working solution of PCB 200 at $1 \mu \mathrm{g} \mathrm{mL}^{-1}$ was prepared in Ac. Matrix-matched calibration curves were prepared by adding the appropriate volume of the standard working solution of standards to blank soil matrix extracts. This matrix extract was obtained by subjecting blank soil samples to the extraction procedure described below. All standard stock solutions, working mix solutions, and matrix-matched calibrators were stored in glass amber vials at $-20^{\circ} \mathrm{C}$, and checked periodically for stability.

\subsection{Sample Collection and Pre-Treatment}

The evaluation of the previously developed method $[46,47]$ and its validation following the parameters required for a scope extension [48] was performed using previously selected agricultural soil samples, which did not present any of the analytes of interest. The blank soil samples employed in the validation experiments were considered representative of the most fertile soil of the Canary archipelago (midlands). Samples were taken from a layer between 20 and $30 \mathrm{~cm}$ deep during the months of February and September, 2020, and mixed to form a pool. First, soil classification of the samples was carried out using standardized procedures, as previously described [47], and it was found that the samples were of the clay-loam type, with acceptable fertility parameters, containing about $4 \%$ oxidizable carbon, and were slightly acidic $(\mathrm{pH}=4.88)$.

For the method performance verification stage, 81 agricultural soil samples were used. All those samples pose similar characteristics to those used for validation. Of these, 35 came from farms dedicated to mixed vegetable cultivation, representative of the most common local agriculture in the Canary Islands (small plots of mixed crops). Nineteen of these farms were dedicated to conventional production (with the use of pesticides), and 16 to organic farming. The rest of the soil samples $(n=46)$ were collected from vineyards, given the significant growth experienced by the wine sector in the archipelago in recent years (which already has 10 denominations of origin). These samples were collected from farms participating in another study and were evenly distributed between conventionally and organically farmed vineyards ( $n=23$ of each type). These samples were taken at a depth of approximately $30 \mathrm{~cm}$. All soil samples were homogenized upon arrival at the laboratory and allowed to air-dry at room temperature. Once dried, they were sieved using a $2 \mathrm{~mm}$ mesh, and thus considered suitable for analysis. 


\subsection{Sample Preparation}

This method is intended as a scope extension of a previously developed method [46,47]; therefore, we did not introduce any variation in the extraction method. Briefly, $10 \pm 0.05 \mathrm{~g}$ of sieved dry soil were weighted in a $50 \mathrm{~mL}$ centrifuge tube. Validation experiment samples and quality controls (QCs) were spiked with the working mixed solution. Next, $50 \mu \mathrm{L}$ of PIS solution were added to all samples and blanks. This addition was performed to account for various sources of error throughout all stages of the method [49]. After the spiked process and the P-IS addition, all samples were mixed vigorously and allowed to stand for $1 \mathrm{~h}$ before extraction. Then, $10 \mathrm{~mL}$ of extraction solution (ACN-2.5\% FA) was added and vigorously shaken for $1 \mathrm{~min}$. Next, QuEChERS-AOAC salts [50] (6 g MgSO 4 and $1.5 \mathrm{~g} \mathrm{CH}_{3} \mathrm{COONa}$ ) were added and samples were vigorously shaken for another minute. After that, samples were sonicated for $15 \mathrm{~min}$ in an ultrasonic bath at $50 / 60 \mathrm{~Hz}, 120 \mathrm{~V}$ (VWR, Radnor, PA, USA) to facilitate the breakdown of aggregates of clay material and increase the contact of the extractant with soil components. The samples were then shaken in an orbital shaker (Ovan, Barcelona, Spain) for $25 \mathrm{~min}$, and subsequently centrifuged at $3200 \times g$ for 10 min (Eppendorf $5804 \mathrm{R}$ centrifuge, Eppendorf, Hamburg, Germany). The supernatants were filtered through $0.20 \mu \mathrm{m}\left(\right.$ Chromafil $^{\circledR}$ PET, Macherey-Nagel, Düren, Germany) into amber vials and directly analyzed by GC-MS/MS.

\subsection{GC-MS/MS Analysis}

All analyses were performed with a gas chromatograph (Agilent GC 7890B) coupled to a mass spectrometer (Agilent Triple Quad 7010) (Agilent Technologies, Palo Alto, CA, USA). Two $15 \mathrm{~m}$ columns (Agilent J\&WHP-5MS, $0.25 \mathrm{~mm}$ inner diameter and $0.25 \mu \mathrm{m}$ film thickness each) were used for the separations. The columns were joined together using a purged junction that allowed the use of the backflushing technique (reversal of the carrier gas flow to remove matrix components once all analytes of interest have passed to the second column). The flow rate of the carrier gas (helium, 99.999\%) was adjusted whenever necessary by means of the retention time (tR) lock function, using chlorpyrifos methyl $(\mathrm{tR}=9.143 \mathrm{~min})$ as a reference. The temperature ramp was programmed as follows: (a) $80^{\circ} \mathrm{C}-1.8 \mathrm{~min}$; (b) $80^{\circ} \mathrm{C}$ to $170{ }^{\circ} \mathrm{C}$ at a rate of $40^{\circ} \mathrm{C} \mathrm{min}-1$; (c) $170{ }^{\circ} \mathrm{C}$ to $310^{\circ} \mathrm{C}$ at a rate of $10^{\circ} \mathrm{C} \mathrm{min}-1$; (d) $310^{\circ} \mathrm{C}$ for $3 \mathrm{~min}$. The total time for each analysis was $20.75 \mathrm{~min}$. For each analysis, $1.5 \mu \mathrm{l}$ of the extract were injected in splitless mode. A $4 \mathrm{~mm}$ ultra-inert liner with glass wool was used. The injector temperature was programmed at $250{ }^{\circ} \mathrm{C}$. Helium backflushing at $5.8 \mathrm{~mL} \mathrm{~min}^{-1}$ at a temperature of $315^{\circ} \mathrm{C}$ for 5 min was used to clean the injector after each analysis.

The MS/MS analyses were performed in multiple reaction monitoring (MRM) mode, for which the spectrometer was programmed in 24 time segments. Depending on the number of MRM transitions in each segment, the cycle time varied within the range 52-334 ms, and the dwell time varied within the range $15-40 \mathrm{~ms}$. The ionization source (electron impact, $70 \mathrm{eV}$ ) was maintained at a temperature of $280^{\circ} \mathrm{C}$. Nitrogen gas of the highest purity available (99.9999\%, Linde, Dublin, Ireland) was used for Q2 fragmentation of the parent ions at a flow rate of $1.5 \mathrm{~mL} \mathrm{~min}^{-1}$. The transfer line temperature was $280^{\circ} \mathrm{C}$. For data acquisition, a delay of $3.7 \mathrm{~min}$ was programmed to allow the solvent front to pass.

\subsection{Method Validation Parameters}

When extending the analytical scope of a method, it is necessary to perform a validation process to verify the ability of the assay to obtain satisfactory results for new analytes. In this work the validation process included the evaluation of linearity, accuracy, precision, calculation of limits of detection (LOD) and quantification (LOQ), and study of the matrix effect. There is no specific guidance for the validation of methods for the analysis of chemical contaminants in soil; therefore, we decided to follow the European Union guidelines for the analysis of pesticides in agricultural products [49,51]. A diagram summarizing the validation process is shown in Figure 1. 


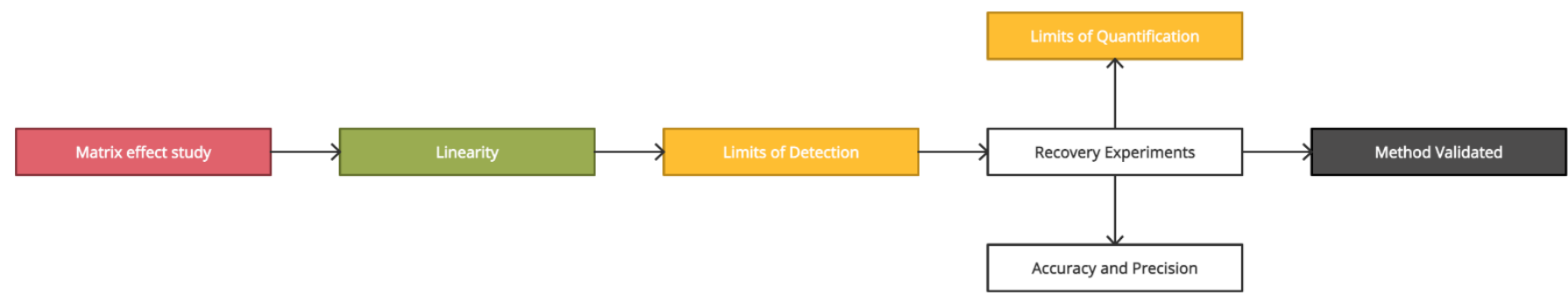

Figure 1. Scheme of the process followed for the method validation.

We first studied the linearity of the response by injecting soil extract samples fortified with all analytes at 9 levels (range $0.39-100 \mathrm{ng} \mathrm{g}^{-1}$ of soil extract). With the data obtained, the linearity of the curve for each analysis was checked by the Mandel test (ISO 8466-1) using Excel v16.46 (Microsoft Corporation, Washington, DC, USA). To determine the accuracy and precision, the percentage recovery (range $70-120 \%$ being acceptable) and percentage relative standard deviation (\%RSD, values $\leq 20 \%$ being acceptable), respectively, were calculated. Recovery experiments were performed on blank soil samples fortified at 7 concentrations (in quintuplicates): $0.5,1.0,2.5,5,10,20$ and $50 \mathrm{ng} \mathrm{g}^{-1}$. The lowest concentration level of each analyte that met the criteria for accuracy and precision was considered as the LOQ. On the other hand, the LODs were calculated by calibration approximation [52]. Thus, the lowest level of the calibration curve that had a signal-tonoise ratio $(\mathrm{S} / \mathrm{N})>3$ and an accuracy between $80-120 \%$ was selected. For this purpose, matrix-adjusted calibration curves in the range of 0.024 to $100 \mathrm{ng} \mathrm{g}^{-1}$ were prepared in triplicate.

For the confirmation of compound identity, 2 MRM transitions were used: one for quantification $(\mathrm{Q})$, and one for confirmation (q). In relation to the standards in the calibration curve, a maximum deviation of $\pm 30 \%$ was tolerated for the ion ratio. In the same way, a maximum deviation of \pm 0.1 min was established for the retention time.

\subsection{Statistical Analysis}

All statistical analyses were performed with Prism v.3 software (GraphPad Software, San Diego, CA, USA), except for the Mandel test, which was calculated in Excel (Microsoft Corporation, Washington, USA). Precision, both within-runs and between-runs, was calculated using a one-way ANOVA with the number of replicates (usually $n=5$ ) as the grouping variable. The fit to normality of contaminant results in soil samples of the monitoring study was assessed by the Kolmogorov-Smirnov test. This test indicated that, in most cases, the concentrations did not follow a normal distribution, therefore the results, in addition to the mean $\pm \mathrm{SD}$, are expressed in terms of median and range. Differences between pairs (conventional vs. organic production farms or mixed vegetable farms vs. vineyards) were tested with the nonparametric Mann-Whitney $U$ test for overall and pairwise comparisons, respectively. For statistical analyses, values below the LOD were assigned a random concentration between 0 and the LOD, and values below the LOQ but above the LOD were assigned a random concentration between these two limits. A $p$-value of less than 0.05 (two-tailed) was considered statistically significant.

\section{Results and Discussion}

\subsection{Optimization of GC-MS/MS Conditions}

First, the GC-MS/MS transitions and chromatographic conditions were optimized by injecting a solution containing the mixture of all the analytes and the P-IS at a concentration of $100 \mathrm{ng} \mathrm{g}^{-1}$ each, both prepared in solvent and in the matrix extracted with the procedure employed in the original method [47]. Transitions were selected from those supplied by Agilent Technologies, but prioritizing selectivity over sensitivity due to the complexity of the soil matrix. Subsequently, the collision energies for each transition were optimized by programming sequences of injections from 5 to $60 \mathrm{eV}$, from which the energy producing 
the highest intensity response was chosen. Finally, we optimized the dwell and cycle time in a similar way. The compounds are shown by groups and in alphabetical order in Table 1 along with their retention time, transitions, and their collision energies.

Table 1. Compounds analyzed in soil with their group, retention time, and mass spectrometric conditions.

\begin{tabular}{|c|c|c|c|c|c|c|c|}
\hline \multirow[b]{2}{*}{ No. } & \multirow[b]{2}{*}{ Compound } & \multirow[b]{2}{*}{ Group $^{a}$} & \multirow[b]{2}{*}{$\mathrm{tR}(\min )$} & \multicolumn{2}{|c|}{ Quantification } & \multicolumn{2}{|c|}{ Confirmation } \\
\hline & & & & $\begin{array}{c}\text { MRM } \\
\text { Transition }(m / z)\end{array}$ & $\mathrm{CE}(\mathrm{eV})$ & $\begin{array}{c}\text { MRM } \\
\text { Transition }(m / z)\end{array}$ & $\mathrm{CE}(\mathrm{eV})$ \\
\hline 1 & PBDE 28 & PBDEs & 12.13 & $406.0 \rightarrow 246.0$ & 20 & $406.0 \rightarrow 167.0$ & 25 \\
\hline 2 & PBDE 47 & PBDEs & 14.21 & $326.0 \rightarrow 138.0$ & 45 & $484.0 \rightarrow 324.0$ & 25 \\
\hline 3 & PBDE 85 & PBDEs & 16.99 & $566.0 \rightarrow 406.0$ & 25 & $564.0 \rightarrow 404.0$ & 25 \\
\hline 4 & PBDE 99 & PBDEs & 16.18 & $566.0 \rightarrow 406.0$ & 25 & $564.0 \rightarrow 404.0$ & 25 \\
\hline 5 & PBDE 100 & PBDEs & 15.76 & $564.0 \rightarrow 404.0$ & 25 & $566.0 \rightarrow 406.0$ & 25 \\
\hline 6 & PBDE 153 & PBDEs & 17.96 & $644.0 \rightarrow 484.0$ & 30 & $486.0 \rightarrow 377.0$ & 30 \\
\hline 7 & PBDE 154 & PBDEs & 17.38 & $644.0 \rightarrow 484.0$ & 30 & $486.0 \rightarrow 377.0$ & 30 \\
\hline 8 & PBDE 183 & PBDEs & 19.98 & $563.6 \rightarrow 454.7$ & 40 & $561.6 \rightarrow 454.7$ & 40 \\
\hline 9 & Aldrin & OCPs & 9.80 & $263.0 \rightarrow 228.0$ & 10 & $255.0 \rightarrow 220.0$ & 20 \\
\hline 10 & Dichlorodiphenyldichloroethane (p,p' DDD) & OCPs & 12.22 & $235.0 \rightarrow 165.0$ & 20 & $235.0 \rightarrow 199.0$ & 30 \\
\hline 11 & Dichlorodiphenyldichloroethylene ( $\mathrm{p}, \mathrm{p}^{\prime}$ DDE) & OCPs & 11.48 & $318.0 \rightarrow 176.0$ & 60 & $318.0 \rightarrow 248.0$ & 15 \\
\hline 12 & Dieldrin & OCPs & 11.58 & $263.0 \rightarrow 228.0$ & 15 & $277.0 \rightarrow 241.0$ & 15 \\
\hline 13 & Endrin & OCPs & 11.94 & $263.0 \rightarrow 193.0$ & 35 & $245.0 \rightarrow 173.0$ & 25 \\
\hline 14 & Heptachlor & OCPs & 9.21 & $272.0 \rightarrow 237.0$ & 15 & $274.0 \rightarrow 239.0$ & 15 \\
\hline 15 & Hexachlorobenzene (HCB) & OCPs & 7.70 & $284.0 \rightarrow 214.0$ & 40 & $284.0 \rightarrow 249.0$ & 25 \\
\hline 16 & Hexachlorocyclohexane (alpha, $\mathrm{HCH}-\alpha$ ) & OCPs & 7.56 & $219.0 \rightarrow 183.0$ & 10 & $219.0 \rightarrow 109.0$ & 10 \\
\hline 17 & Hexachlorocyclohexano (beta, $\mathrm{HCH}-\beta$ ) & OCPs & 7.93 & $219.0 \rightarrow 183.0$ & 10 & $219.0 \rightarrow 109.0$ & 10 \\
\hline 18 & Hexaclorociclohexano (delta, $\mathrm{HCH}-\delta$ ) & OCPs & 8.43 & $219.0 \rightarrow 183.0$ & 15 & $219.0 \rightarrow 109.0$ & 45 \\
\hline 19 & $\begin{array}{l}\text { Hexachlorocyclohexane } \\
\text { (gamma, HCH- } \gamma \text {, lindane) }\end{array}$ & OCPs & 8.13 & $219.0 \rightarrow 183.0$ & 10 & $219.0 \rightarrow 109.0$ & 10 \\
\hline 20 & Mirex & OCPs & 14.68 & $272.0 \rightarrow 237.0$ & 10 & $274.0 \rightarrow 237.0$ & 10 \\
\hline 21 & Acenaphthene & PAHs & 6.10 & $153.0 \rightarrow 152.0$ & 25 & $153.0 \rightarrow 151.0$ & 35 \\
\hline 22 & Acenaphthylene & PAHs & 5.89 & $152.0 \rightarrow 151.0$ & 25 & $152.0 \rightarrow 126.0$ & 30 \\
\hline 23 & Anthracene & PAHs & 8.47 & $178.0 \rightarrow 152.0$ & 28 & $178.0 \rightarrow 176.0$ & 35 \\
\hline 24 & Benzo[a]anthracene & PAHs & 13.74 & $228.0 \rightarrow 226.0$ & 40 & $228.0 \rightarrow 202.0$ & 35 \\
\hline 25 & Benzo[b]fluoranthene & PAHs & 16.15 & $252.0 \rightarrow 224.0$ & 60 & $252.0 \rightarrow 248.0$ & 60 \\
\hline 26 & Chrysene & PAHs & 14.01 & $228.0 \rightarrow 226.0$ & 40 & $228.0 \rightarrow 227.0$ & 25 \\
\hline 27 & Fluoranthene & PAHs & 10.58 & $202.0 \rightarrow 201.0$ & 27 & $202.0 \rightarrow 152.0$ & 42 \\
\hline 28 & Fluorene & PAHs & 6.75 & $165.0 \rightarrow 163.0$ & 40 & $165.0 \rightarrow 139.0$ & 32 \\
\hline 29 & Naphthalene & PAHs & 4.42 & $128.0 \rightarrow 102.0$ & 25 & $128.0 \rightarrow 127.0$ & 15 \\
\hline 30 & Phenanthrene & PAHs & 8.23 & $178.0 \rightarrow 176.0$ & 35 & $178.0 \rightarrow 152.0$ & 28 \\
\hline 31 & Pyrene & PAHs & 11.04 & $202.0 \rightarrow 200.0$ & 45 & $202.0 \rightarrow 201.0$ & 27 \\
\hline 32 & PCB 28 & PCBs & 8.94 & $256.0 \rightarrow 186.0$ & 25 & $256.0 \rightarrow 151.0$ & 50 \\
\hline 33 & РCB 52 & PCBs & 9.49 & $292.0 \rightarrow 222.0$ & 25 & $292.0 \rightarrow 220.0$ & 25 \\
\hline 34 & PCB 77 & PCBs & 11.65 & $292.0 \rightarrow 222.0$ & 25 & $292.0 \rightarrow 220.0$ & 25 \\
\hline 35 & PCB 81 & PCBs & 11.47 & $292.0 \rightarrow 222.0$ & 25 & $292.0 \rightarrow 220.0$ & 25 \\
\hline 36 & PCB 101 & PCBs & 10.98 & $326.0 \rightarrow 256.0$ & 30 & $328.0 \rightarrow 256.0$ & 30 \\
\hline 37 & РCB 105 & PCBs & 12.56 & $326.0 \rightarrow 256.0$ & 30 & $328.0 \rightarrow 256.0$ & 30 \\
\hline 38 & РСВ 114 & PCBs & 12.29 & $326.0 \rightarrow 256.0$ & 30 & $328.0 \rightarrow 256.0$ & 30 \\
\hline 39 & PCB 118 & PCBs & 12.15 & $326.0 \rightarrow 256.0$ & 30 & $328.0 \rightarrow 256.0$ & 30 \\
\hline 40 & РСВ 123 & PCBs & 12.01 & $326.0 \rightarrow 256.0$ & 30 & $328.0 \rightarrow 256.0$ & 30 \\
\hline 41 & PCB 126 & PCBs & 13.14 & $326.0 \rightarrow 256.0$ & 30 & $328.0 \rightarrow 256.0$ & 30 \\
\hline 42 & РCB 138 & PCBs & 12.97 & $360.0 \rightarrow 290.0$ & 25 & $360.0 \rightarrow 288.0$ & 25 \\
\hline 43 & PCB 153 & PCBs & 12.47 & $360.0 \rightarrow 290.0$ & 25 & $360.0 \rightarrow 288.0$ & 25 \\
\hline 44 & РCB 156 & PCBs & 13.86 & $360.0 \rightarrow 290.0$ & 25 & $360.0 \rightarrow 288.0$ & 25 \\
\hline 45 & РCB 157 & PCBs & 13.96 & $360.0 \rightarrow 290.0$ & 25 & $360.0 \rightarrow 288.0$ & 25 \\
\hline 46 & PCB 167 & PCBs & 13.45 & $360.0 \rightarrow 290.0$ & 25 & $360.0 \rightarrow 288.0$ & 25 \\
\hline 47 & РCВ 169 & PCBs & 14.52 & $360.0 \rightarrow 290.0$ & 25 & $360.0 \rightarrow 288.0$ & 25 \\
\hline 48 & PCB 180 & PCBs & 14.14 & $394.0 \rightarrow 324.0$ & 30 & $394.0 \rightarrow 322.0$ & 30 \\
\hline \multirow[t]{2}{*}{49} & РСВ 189 & PCBs & 15.15 & $394.0 \rightarrow 324.0$ & 30 & $394.0 \rightarrow 322.0$ & 30 \\
\hline & PCB 200 & P-IS & 14.46 & $427.8 \rightarrow 357.8$ & 30 & $429.8 \rightarrow 359.8$ & 30 \\
\hline
\end{tabular}

CE-Collision Energy; $\mathrm{tR}$ - Retention time. ${ }^{\text {a }}$ PBDE—Polybrominated diphenyl ethers; OCP-Organochlorine pesticides; PAH—Polycyclic aromatic hydrocarbon; PCB-Polychlorinated biphenyl; P-IS-Procedural Internal Standard.

We decided to avoid the evaporation and solvent change steps and to inject the final extract as it was obtained (directly into acetonitrile), to avoid the loss of the more volatile compounds. Moreover, $\mathrm{ACN}$ has proven to be a good solvent for use in gas chromatography, as stated by Mastovska et al. [53] and from our own studies on pesticides of current or recent use in this matrix [46,47]. No optimization was performed regarding the 
chromatographic conditions (column and temperature program); being a scope extension, we cannot introduce changes to the original method because we would run the risk of modifying the conditions under which the 218 compounds included in that study were validated. Figure 2 shows the chromatogram of a blank soil sample spiked at $50 \mathrm{ng} \mathrm{g}^{-1}$ with the target analytes and P-IS in GC-MS/MS analysis.

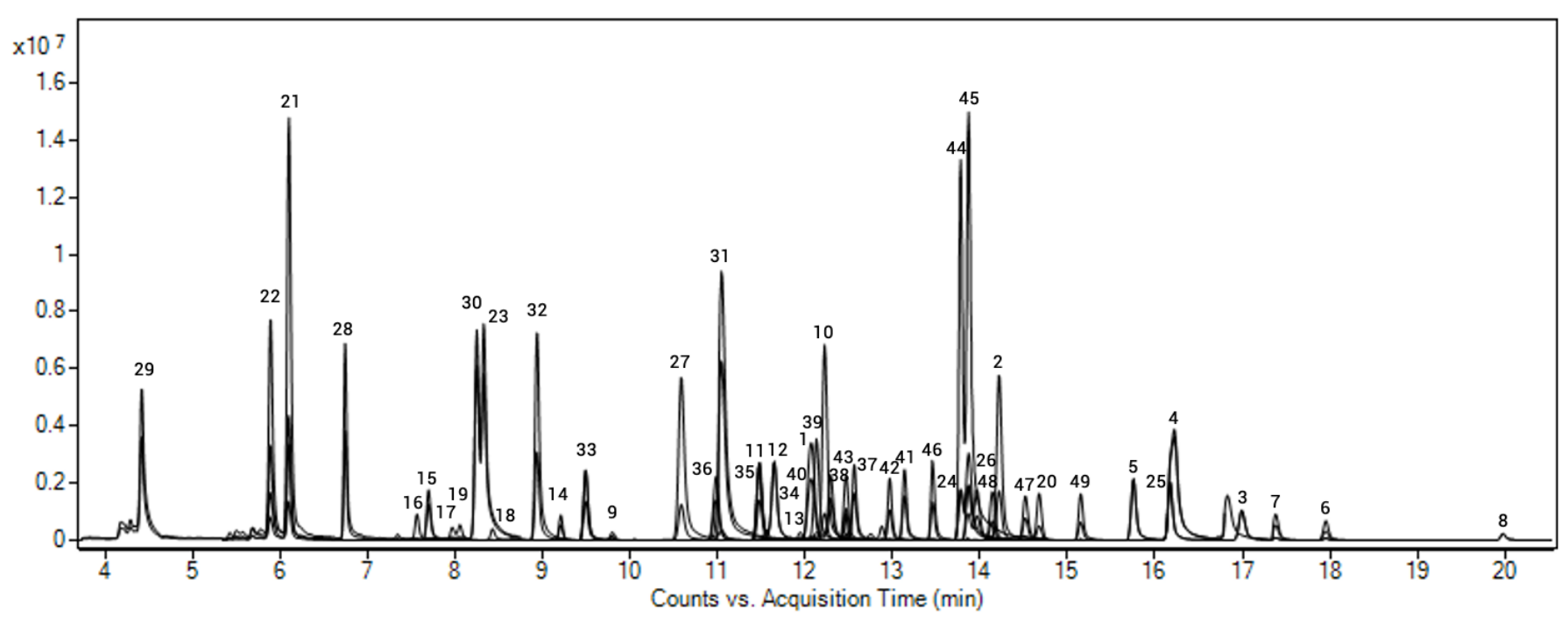

Figure 2. GC-MS/MS chromatogram of a blank soil sample spiked with the selected POPs at $50 \mathrm{ng} \mathrm{g}^{-1}$.

\subsection{Matrix Effect Study}

A matrix effect study was run to evaluate the possible interferences of the soil components in the equipment signal. The soil matrix is extremely complex, and its constituents can either enhance or suppress the response, compromising the accuracy, sensitivity, and selectivity of the chromatographic method [54]. In gas chromatography, the presence of high amounts of matrix components could protect the analyte from adsorption or degradation during evaporation in the inlet [55].

We evaluated the matrix effect by comparing the slopes of the calibration curves prepared in the solvent and matrix extracted in the previously detailed conditions according to the equation:

$$
\operatorname{ME}(\%)=\left(S_{m} / S_{s}\right) \times 100
$$

where ME represents the matrix effect as a percentage, and $S_{s}$ and $S_{m}$ are the slopes of the curve prepared in the solvent and matrix, respectively. The effect of the matrix components on the signal is qualified as the percentage of enhancement or suppression, whether the ME values are above or below $100 \%$, respectively. In accordance to SANCO guidelines, the tolerance range where no significant matrix effects were considered was established as between $80 \%$ and $120 \%$ [51].

The calibration curves covered the range of 3.125 to $50 \mathrm{ng} \mathrm{g}^{-1}$ and were prepared in triplicate, either in the soil matrix or in ACN 2.5\%FA, which was the solvent of the final extract. All curves were adjusted to a linear regression curve:

$$
\mathrm{Y}=\mathrm{ax}+\mathrm{b}
$$

where $a$ is the slope and $b$ the intercept. These values were used to calculate $\mathrm{ME} \%$ using Equation (1).

Figure 3 shows the ME (\%) values for each compound, which are listed following the order assigned in Table 1. Each chemical group has been represented with a different color. 


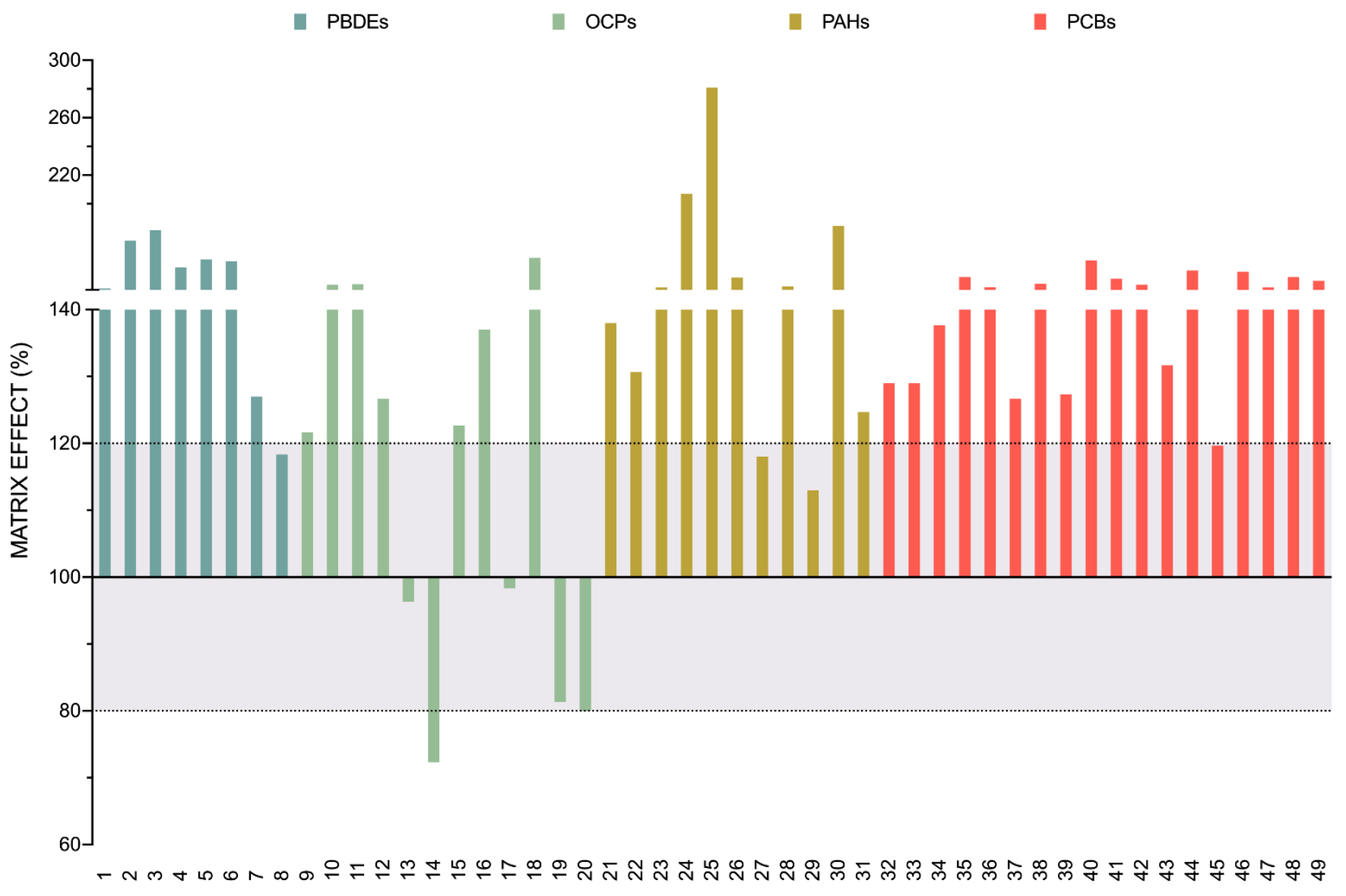

Figure 3. Matrix effect. Bars represent the mean of the $\mathrm{ME} \%$ of the analytes. Dotted lines represent the tolerance range in which it is considered that no significant matrix effect exists.

As can be seen, most of the compounds analyzed showed significant matrix effects, except for eight of them (PBDE 183, Endrin, Hexachlorocyclohexane (beta), Hexachlorocyclohexane (gamma-lindane), Mirex, Fluoranthene, Naphthalene, and PCB 157), which were within the limits established for a non-significant matrix effect. The most marked trend was enhancement, although five of the compounds, all of them OCPs, showed no significant to low significant suppression. More than half of the compounds (26 out of 49) had a matrix effect superior to $140 \%$, with Benzo[b]fluoranthene having the highest matrix effect $(281 \%)$. These data evidence the importance of evaluating the matrix effect in this equipment and the need to use matrix-matched calibration curves in routine analyses of POPs in soil samples.

\subsection{Method Validation}

The method was validated to the extraction and quantitative determination of the above-mentioned POPs under the terms stated in the "Method Validation Parameters" section.

The linearity in the response $\left(\mathrm{R}^{2}\right)$ was superior to 0.99 for all the analytes in the studied range (Table 2). The results of the recovery experiments are presented in Table 3. In terms of accuracy and precision, most compounds met the validation criteria (recoveries between $70 \%$ and $120 \%$ and RSD $<20 \%$ ) for concentration between their LOQ and the highest level studied $\left(50 \mathrm{ng} \mathrm{g}^{-1}\right)$. The highest level studied was set at $50 \mathrm{ng} \mathrm{g}^{-1}$, which is the commonly accepted value for residues in soils [51]. There were some exceptions where recoveries were outside the mentioned range. However, these cases were contemplated in the SANTE guidelines, which accept a recovery between $60 \%$ and $140 \%$ as long as the RSD is below $20 \%$ [49]. Similarly, in some cases, recoveries were within the established limits with RSD 
slightly higher than $20 \%$, which is considered for residues in soils at concentrations equal to or lower than $10 \mathrm{ng} \mathrm{g}^{-1}$ [51].

Table 2. Linear studies, limits of detection (LOD), and limits of quantification (LOQ) of the POPs.

\begin{tabular}{|c|c|c|c|c|c|}
\hline No. & Compound & Group & $\mathbf{R}^{2}$ & LOD (ng g $\left.{ }^{-1}\right)$ & LOQ $\left(\operatorname{ng~g~}^{-1}\right)$ \\
\hline 1 & PBDE 28 & PBDEs & 0.9997 & 0.390 & 1.0 \\
\hline 2 & PBDE 47 & PBDEs & 0.9984 & 0.195 & 1.0 \\
\hline 3 & PBDE 85 & PBDEs & 0.9982 & 0.780 & 1.0 \\
\hline 4 & PBDE 99 & PBDEs & 0.9984 & 0.390 & 1.0 \\
\hline 5 & PBDE 100 & PBDEs & 0.9966 & 0.195 & 1.0 \\
\hline 6 & PBDE 153 & PBDEs & 0.9990 & 0.195 & 1.0 \\
\hline 7 & PBDE 154 & PBDEs & 0.9984 & 0.390 & 1.0 \\
\hline 8 & PBDE 183 & PBDEs & 0.9981 & 0.195 & 0.5 \\
\hline 9 & Aldrin & OCPs & 0.9976 & 0.390 & 1.0 \\
\hline 10 & $p, p^{\prime}$ DDD & OCPs & 0.9993 & 1.560 & 2.5 \\
\hline 11 & $\mathrm{p}, \mathrm{p}^{\prime} \mathrm{DDE}$ & OCPs & 0.9975 & 0.390 & 2.5 \\
\hline 12 & Dieldrin & OCPs & 0.9951 & 1.560 & 5.0 \\
\hline 13 & Endrin & OCPs & 0.9910 & 1.560 & 2.5 \\
\hline 14 & Heptachlor & OCPs & 0.9987 & 0.097 & 0.5 \\
\hline 15 & HCB & OCPs & 0.9997 & 0.390 & 1.0 \\
\hline 16 & $\mathrm{HCH}-\alpha$ & OCPs & 0.9948 & 1.560 & 2.5 \\
\hline 17 & $\mathrm{HCH}-\beta$ & OCPs & 0.9989 & 1.560 & 2.5 \\
\hline 18 & $\mathrm{HCH}-\delta$ & OCPs & 0.9992 & 1.560 & 2.5 \\
\hline 19 & Lindane & OCPs & 0.9993 & 1.560 & 5.0 \\
\hline 20 & Mirex & OCPs & 0.9988 & 0.390 & 1.0 \\
\hline 21 & Acenaphthene & PAHs & 0.9972 & 0.780 & 2.5 \\
\hline 22 & Acenaphthylene & PAHs & 0.9962 & 0.780 & 1.0 \\
\hline 23 & Anthracene & PAHs & 0.9993 & 0.780 & 5.0 \\
\hline 24 & Benzo[a]anthracene & PAHs & 0.9932 & 0.780 & 20.0 \\
\hline 25 & Benzo[b]fluoranthene & PAHs & 0.9967 & 1.560 & 10.0 \\
\hline 26 & Chrysene & PAHs & 0.9912 & 0.780 & 10.0 \\
\hline 27 & Fluoranthene & PAHs & 0.9963 & 0.780 & 20.0 \\
\hline 28 & Fluorene & PAHs & 0.9980 & 0.390 & 1.0 \\
\hline 29 & Naphthalene & PAHs & 0.9978 & 3.125 & 50.0 \\
\hline 30 & Phenanthrene & PAHs & 0.9991 & 0.780 & 5.0 \\
\hline 31 & Pyrene & PAHs & 0.9993 & 0.780 & 10.0 \\
\hline 32 & PCB 28 & PCBs & 0.9997 & 0.097 & 1.0 \\
\hline 33 & PCB 52 & PCBs & 0.9986 & 0.195 & 1.0 \\
\hline 34 & PCB 77 & PCBs & 0.9995 & 0.195 & 1.0 \\
\hline 35 & PCB 81 & PCBs & 0.9947 & 0.780 & 1.0 \\
\hline 36 & PCB 101 & PCBs & 0.9995 & 0.390 & 1.0 \\
\hline 37 & РCB 105 & PCBs & 0.9963 & 0.097 & 1.0 \\
\hline 38 & РCB 114 & PCBs & 0.9993 & 0.195 & 1.0 \\
\hline 39 & PCB 118 & PCBs & 0.9968 & 0.195 & 1.0 \\
\hline 40 & РCВ 123 & PCBs & 0.9992 & 0.097 & 1.0 \\
\hline 41 & PCB 126 & PCBs & 0.9999 & 0.097 & 1.0 \\
\hline 42 & РСВ 138 & PCBs & 0.9996 & 0.048 & 1.0 \\
\hline 43 & PCB 153 & PCBs & 0.9997 & 0.390 & 1.0 \\
\hline 44 & РCВ 156 & PCBs & 0.9990 & 0.390 & 1.0 \\
\hline 45 & РCB 157 & PCBs & 0.9978 & 0.390 & 1.0 \\
\hline 46 & PCB 167 & PCBs & 0.9990 & 0.390 & 1.0 \\
\hline 47 & РCB 169 & PCBs & 0.9983 & 0.390 & 1.0 \\
\hline 48 & РCВ 180 & PCBs & 0.9943 & 0.78 & 1.0 \\
\hline 49 & РСВ 189 & PCBs & 0.9992 & 0.195 & 1.0 \\
\hline
\end{tabular}


Table 3. Method validation results: percentage recoveries and relative standard deviations (in brackets).

\begin{tabular}{|c|c|c|c|c|c|c|c|c|c|}
\hline No. & Compound & Group & $0.5 \operatorname{ng~g}^{-1}$ & $1.0 \mathrm{ng} \mathrm{g}^{-1}$ & $2.5 \mathrm{ng} \mathrm{g}^{-1}$ & $5.0 \mathrm{ng} \mathrm{g}^{-1}$ & $10.0 \mathrm{ng} \mathrm{g}^{-1}$ & $20.0 \mathrm{ng} \mathrm{g}^{-1}$ & $50.0 \mathrm{ng} \mathrm{g}^{-1}$ \\
\hline 1 & PBDE 28 & PBDEs & $\mathrm{N} / \mathrm{A}$ & $106.8(12.3)$ & $116.4(16.6)$ & $101.1(6.7)$ & $122.9(20.7)$ & $105.7(7.5)$ & $105.0(6.4)$ \\
\hline 2 & PBDE 47 & PBDEs & $\mathrm{N} / \mathrm{A}$ & $98.7(5.5)$ & $102.7(9.3)$ & $97.8(2.9)$ & 114.5 (11.6) & $99.3(4.6)$ & $103.1(4.8)$ \\
\hline 3 & PBDE 85 & PBDEs & $\mathrm{N} / \mathrm{A}$ & 92.5 (7.9) & 100.7 (13.7) & 88.1 (7.6) & 104.1 (11.9) & 91.7 (15.7) & $99.3(9.8)$ \\
\hline 4 & PBDE 99 & PBDEs & $\mathrm{N} / \mathrm{A}$ & $107.8(9.7)$ & $107.0(11.0)$ & $92.3(10.4)$ & $102.1(15.4)$ & $96.2(15.3)$ & $103.1(9.7)$ \\
\hline 5 & PBDE 100 & PBDEs & $\mathrm{N} / \mathrm{A}$ & 97.9 (11.6) & $108.4(10.9)$ & $91.5(3.5)$ & $112.0(13.0)$ & $103.6(6.4)$ & $104.6(5.9)$ \\
\hline 6 & PBDE 153 & PBDEs & $\mathrm{N} / \mathrm{A}$ & $95.0(9.6)$ & $103.3(11.2)$ & $86.2(4.6)$ & $99.4(15.2)$ & $89.9(8.9)$ & $96.1(9.8)$ \\
\hline 7 & PBDE 154 & PBDEs & $\mathrm{N} / \mathrm{A}$ & $100.1(2.4)$ & $99.5(11.4)$ & $86.6(6.2)$ & $94.3(14.2)$ & $87.1(11.2)$ & $94.2(7.5)$ \\
\hline 8 & PBDE 183 & PBDEs & 117.1 (15.3) & $80.6(10.8)$ & $95.3(8.1)$ & $83.5(6.3)$ & $96.3(19.1)$ & $87.3(9.4)$ & $85.6(4.8)$ \\
\hline 9 & Aldrin & OCPs & $\mathrm{N} / \mathrm{A}$ & $106.2(17.0)$ & $112.1(11.1)$ & $99.9(13.0)$ & $112.5(12.1)$ & $100.7(4.3)$ & $102.2(5.8)$ \\
\hline 10 & $\mathrm{p}, \mathrm{p}^{\prime} \mathrm{DDD}$ & OCPs & $\mathrm{N} / \mathrm{A}$ & $\mathrm{N} / \mathrm{A}$ & $105.2(18.8)$ & $89.9(4.4)$ & $97.5(17.2)$ & $89.2(3.1)$ & 86.7 (5.1) \\
\hline 11 & $\mathrm{p}, \mathrm{p}^{\prime} \mathrm{DDE}$ & OCPs & $\mathrm{N} / \mathrm{A}$ & $\mathrm{N} / \mathrm{A}$ & $101.3(13.3)$ & $81.8(10.8)$ & $107.4(11.0)$ & $103.5(6.1)$ & $107.7(9.9)$ \\
\hline 12 & Dieldrin & OCPs & $\mathrm{N} / \mathrm{A}$ & $\mathrm{N} / \mathrm{A}$ & $\mathrm{N} / \mathrm{A}$ & $77.5(10.0)$ & $116.7(10.7)$ & $104.0(4.9)$ & $96.5(6.2)$ \\
\hline 13 & Endrin & OCPs & $\mathrm{N} / \mathrm{A}$ & $\mathrm{N} / \mathrm{A}$ & $90.8(11.1)$ & $77.3(9.1)$ & $72.1(12.8)$ & $69.2(11.5)$ & $67.9(9.0)$ \\
\hline 14 & Heptachlor & OCPs & $99.4(13.3)$ & $69.8(13.5)$ & $88.3(27.1)$ & $74.3(7.1)$ & $85.4(21.5)$ & $84.3(10.4)$ & $82.0(16.8)$ \\
\hline 15 & $\mathrm{HCB}$ & OCPs & N/A & $104.2(8.5)$ & $111.4(7.0)$ & $102.0(4.9)$ & $110.0(14.6)$ & $101.4(4.3)$ & $103.9(3.5)$ \\
\hline 16 & $\mathrm{HCH}-\alpha$ & OCPs & $\mathrm{N} / \mathrm{A}$ & $\mathrm{N} / \mathrm{A}$ & $119.6(7.6)$ & $101.9(4.4)$ & $100.1(15.0)$ & $89.3(10.1)$ & $95.3(18.2)$ \\
\hline 17 & $\mathrm{HCH}-\beta$ & OCPs & $\mathrm{N} / \mathrm{A}$ & $\mathrm{N} / \mathrm{A}$ & $99.2(12.7)$ & $86.3(9.6)$ & $98.3(22.7)$ & 99.5 (19.3) & $84.6(7.3)$ \\
\hline 18 & $\mathrm{HCH}-\delta$ & OCPs & $\mathrm{N} / \mathrm{A}$ & $\mathrm{N} / \mathrm{A}$ & $81.8(16.4)$ & $77.7(5.5)$ & $93.8(23.1)$ & $89.9(6.7)$ & $86.6(7.1)$ \\
\hline 19 & Lindane & OCPs & $\mathrm{N} / \mathrm{A}$ & $\mathrm{N} / \mathrm{A}$ & $\mathrm{N} / \mathrm{A}(\mathrm{N} / \mathrm{A})$ & $76.9(15.7)$ & $94.9(31.6)$ & 94.7 (20.9) & $84.1(5.4)$ \\
\hline 20 & Mirex & OCPs & $\mathrm{N} / \mathrm{A}$ & $82.7(13.9)$ & $84.5(19.3)$ & $72.7(7.5)$ & $83.3(14.6)$ & $78.4(7.9)$ & $79.9(7.3)$ \\
\hline 21 & Acenaphthene & PAHs & $\mathrm{N} / \mathrm{A}$ & $\mathrm{N} / \mathrm{A}$ & 112.7 (18.6) & $117.2(12.9)$ & $130.4(19.6)$ & $130.8(8.9)$ & $122.9(4.0)$ \\
\hline 22 & Acenaphthylene & PAHs & $\mathrm{N} / \mathrm{A}$ & $117.9(10.7)$ & $116.8(8.1)$ & $115.3(6.3)$ & $118.3(15.6)$ & $123.1(12.6)$ & $112.6(5.7)$ \\
\hline 23 & Anthracene & PAHs & $\mathrm{N} / \mathrm{A}$ & $\mathrm{N} / \mathrm{A}$ & $\mathrm{N} / \mathrm{A}$ & $104.8(8.7)$ & $103.5(13.9)$ & $101.9(2.6)$ & $100.9(8.8)$ \\
\hline 24 & Benzo[a]anthracene & PAHs & $\mathrm{N} / \mathrm{A}$ & $\mathrm{N} / \mathrm{A}$ & $\mathrm{N} / \mathrm{A}$ & $\mathrm{N} / \mathrm{A}$ & $\mathrm{N} / \mathrm{A}$ & $76.5(12.1)$ & $86.5(10.5)$ \\
\hline 25 & Benzo[b]fluoranthene & PAHs & $\mathrm{N} / \mathrm{A}$ & $\mathrm{N} / \mathrm{A}$ & $\mathrm{N} / \mathrm{A}$ & $\mathrm{N} / \mathrm{A}$ & $63.2(12.7)$ & $67.1(14.1)$ & $71.7(9.3)$ \\
\hline 26 & Chrysene & PAHs & $\mathrm{N} / \mathrm{A}$ & $\mathrm{N} / \mathrm{A}$ & $\mathrm{N} / \mathrm{A}$ & $\mathrm{N} / \mathrm{A}$ & $70.1(19.7)$ & $68.4(10.0)$ & $76.1(10.8)$ \\
\hline 27 & Fluoranthene & PAHs & $\mathrm{N} / \mathrm{A}$ & $\mathrm{N} / \mathrm{A}$ & $\mathrm{N} / \mathrm{A}$ & $\mathrm{N} / \mathrm{A}$ & $\mathrm{N} / \mathrm{A}$ & $109.2(14.1)$ & $106.9(9.7)$ \\
\hline 28 & Fluorene & PAHs & $\mathrm{N} / \mathrm{A}$ & $109.4(17.3)$ & $113.1(10.3)$ & $121.9(2.7)$ & $126.8(19.6)$ & $121.0(9.9)$ & $122.5(5.9)$ \\
\hline 29 & Naphthalene & PAHs & $\mathrm{N} / \mathrm{A}$ & $\mathrm{N} / \mathrm{A}$ & $\mathrm{N} / \mathrm{A}$ & $\mathrm{N} / \mathrm{A}$ & $\mathrm{N} / \mathrm{A}$ & N/A & $116.8(4.0)$ \\
\hline 30 & Phenanthrene & PAHs & $\mathrm{N} / \mathrm{A}$ & $\mathrm{N} / \mathrm{A}$ & $\mathrm{N} / \mathrm{A}$ & $113.8(13.6)$ & $120.1(19.1)$ & $120.3(6.4)$ & $113.3(7.0)$ \\
\hline 31 & Pyrene & PAHs & $\mathrm{N} / \mathrm{A}$ & $\mathrm{N} / \mathrm{A}$ & $\mathrm{N} / \mathrm{A}$ & $\mathrm{N} / \mathrm{A}$ & $113.4(19.8)$ & $104.0(15.5)$ & $102.9(11.4)$ \\
\hline 32 & PCB 28 & PCBs & $\mathrm{N} / \mathrm{A}$ & $102.6(10.5)$ & $114.5(9.2)$ & $108.1(7.3)$ & $120.6(15.7)$ & $112.7(5.1)$ & $112.9(5.4)$ \\
\hline 33 & PCB 52 & PCBs & $\mathrm{N} / \mathrm{A}$ & $106.6(5.8)$ & $119.2(6.9)$ & $106.9(4.6)$ & $126.0(11.8)$ & $110.1(3.8)$ & $105.5(5.0)$ \\
\hline 34 & PCB 77 & PCBs & $\mathrm{N} / \mathrm{A}$ & $98.3(4.2)$ & $108.7(7.4)$ & $106.8(6.8)$ & $114.2(11.1)$ & $103.3(3.5)$ & $98.7(7.0)$ \\
\hline 35 & PCB 81 & PCBs & $\mathrm{N} / \mathrm{A}$ & $107.0(7.6)$ & $105.6(4.1)$ & $93.6(4.2)$ & $106.2(11.5)$ & $97.3(5.8)$ & $109.8(9.6)$ \\
\hline 36 & РCB 101 & PCBs & $\mathrm{N} / \mathrm{A}$ & $101.0(4.9)$ & $111.5(9.2)$ & $107.6(8.0)$ & $126.7(16.1)$ & $111.5(5.6)$ & $107.5(6.1)$ \\
\hline 37 & PCB 105 & PCBs & $\mathrm{N} / \mathrm{A}$ & $90.6(8.0)$ & $102.8(15.6)$ & $99.4(11.2)$ & $112.2(11.8)$ & $108.8(5.1)$ & 110.5 (2.9) \\
\hline 38 & РCB 114 & PCBs & $\mathrm{N} / \mathrm{A}$ & $107.5(12.6)$ & $110.6(10.9)$ & $102.9(5.4)$ & 117.1 (19.5) & $104.1(6.5)$ & $107.2(4.5)$ \\
\hline 39 & РCB 118 & PCBs & $\mathrm{N} / \mathrm{A}$ & 108.7 (13.9) & $109.8(10.7)$ & $100.8(8.6)$ & 110.5 (15.4) & $97.7(4.1)$ & $100.4(20.3)$ \\
\hline 40 & РCB 123 & PCBs & $\mathrm{N} / \mathrm{A}$ & $114.8(9.5)$ & $131.9(7.3)$ & $128.1(6.0)$ & 136.5 (13.5) & $123.1(4.9)$ & $111.2(2.2)$ \\
\hline 41 & PCB 126 & PCBs & $\mathrm{N} / \mathrm{A}$ & $102.1(8.6)$ & $111.0(9.2)$ & $114.2(6.3)$ & $115.4(13.9)$ & $98.9(6.2)$ & $91.7(5.8)$ \\
\hline 42 & PCB 138 & PCBs & $\mathrm{N} / \mathrm{A}$ & $92.3(10.0)$ & 108.7 (17.7) & 111.7 (7.7) & $120.3(22.5)$ & 88.6 (12.7) & $81.5(8.3)$ \\
\hline 43 & PCB 153 & PCBs & $\mathrm{N} / \mathrm{A}$ & $103.6(15.3)$ & $109.2(5.6)$ & $110.0(6.2)$ & $121.6(15.9)$ & $105.5(4.3)$ & $104.5(3.2)$ \\
\hline 44 & РCB 156 & PCBs & $\mathrm{N} / \mathrm{A}$ & $102.0(6.1)$ & $110.6(3.5)$ & $107.1(10.1)$ & $109.2(9.9)$ & $98.1(10.5)$ & $88.5(6.9)$ \\
\hline 45 & РCB 157 & PCBs & $\mathrm{N} / \mathrm{A}$ & 103.5 (12.7) & $102.5(9.1)$ & $97.0(6.0)$ & $103.3(19.1)$ & $95.5(5.6)$ & $103.3(14.5)$ \\
\hline 46 & PCB 167 & PCBs & $\mathrm{N} / \mathrm{A}$ & 102.1 (9.9) & 106.5 (10.7) & $101.9(5.4)$ & $110.9(16.1)$ & $101.3(4.7)$ & $105.3(7.6)$ \\
\hline 47 & РCВ 169 & PCBs & $\mathrm{N} / \mathrm{A}$ & $108.2(8.5)$ & $100.9(8.7)$ & $96.1(4.5)$ & $106.4(12.5)$ & $93.7(4.4)$ & $101.1(6.5)$ \\
\hline 48 & PCB 180 & PCBs & $\mathrm{N} / \mathrm{A}$ & $104.5(6.4)$ & $100.0(16.6)$ & $97.3(5.6)$ & $102.0(10.5)$ & $87.3(3.9)$ & $99.0(10.1)$ \\
\hline 49 & РCВ 189 & PCBs & $\mathrm{N} / \mathrm{A}$ & $104.9(8.6)$ & $114.9(2.3)$ & $103.7(2.1)$ & $118.4(12.6)$ & $103.9(11.5)$ & $95.9(6.5)$ \\
\hline
\end{tabular}

The LODs were established as between 0.048 and $3.125 \mathrm{ng} \mathrm{g}^{-1}$, and the LOQs were between 0.5 and $20 \mathrm{ng} \mathrm{g}^{-1}$, except for naphthalene; more than one-half of the analytes had a quantification limit of $1 \mathrm{ng} \mathrm{g}^{-1}$ or below (Table 2). For groups, all PCBs and PBDEs had this limit except for PBDE 183, which had a lower limit value $\left(0.5 \mathrm{ng} \mathrm{g}^{-1}\right)$; OCPs had a maximum LOQ of $2.5 \mathrm{ng} \mathrm{g}^{-1}$; and PAHs had the highest variability in LOQ values, one reaching $50 \mathrm{ng} \mathrm{g}^{-1}$ (naphthalene).

The proposed extraction and analytical methods were validated and proved to be reliable and accurate for the analyses of POPs residues in soils.

\subsection{Application to Agricultural Soil Samples}

To verify the performance of the validated method, it was applied to the monitoring of a series of 81 farms in seven of the eight islands of the Canary archipelago (Spain). In $28.4 \%$ of the farms $(n=23)$ no residues were detected, and in the others, the range was between 2 
and 10 different residues per farm. In total, we detected 17 different contaminants (4 OCPs, 11 PAHs, and 2 PCBs were detected).

It is striking that no PBDEs were detected in any of the farms, because they are described in the literature as frequent contaminants of agricultural soil [56-58]; however, it is true that the reported concentrations are mainly related to the use of treated wastewater [57], or to highly industrialized countries [58]. Previous studies have shown that the rate of flame retardant contamination in the Canary Islands is relatively low $[17,18,38]$, which has been related to the relatively low industrial activity in this region $[59,60]$. This is probably also the reason why only two PCBs were detected in our samples and at very low concentrations (Tables 3 and 4), unlike what is reported in agricultural soils from more industrialized regions [61,62], where the reported concentrations are several orders of magnitude higher. Something similar occurred in our series with PAHs; although they were frequently detected, this was mainly due to the high sensitivity of the analytical method, because the concentrations detected were very low (mean $\sum \mathrm{PAHs}=2.9 \pm 7.2 \mathrm{ng} \mathrm{g}^{-1}$, median $=0.0 \mathrm{ng} \mathrm{g}^{-1}$ ). These concentrations are considerably lower than those reported in highly industrialized countries or regions, in the order of 70 [63] to 50,000 times [64] lower.

Table 4. Comparative study of the POPs detected in 44 samples of agricultural soil of farms of conventional production and 37 samples from farms of organic production. Concentrations are expressed in $\mu \mathrm{g} \mathrm{kg}^{-1}$.

\begin{tabular}{|c|c|c|c|c|c|c|c|c|c|}
\hline \multirow[b]{2}{*}{ Compound } & \multicolumn{4}{|c|}{ Conventional Production } & \multicolumn{4}{|c|}{ Organic Production } & \multirow[b]{2}{*}{$p$-Value } \\
\hline & Mean \pm SD & Median & P25-P75 & Freq. (\%) & Mean \pm SD & Median & P25-P75 & Freq. (\%) & \\
\hline DDE & $170.6 \pm 309.9$ & 5.3 & $0.3-156.9$ & 68.2 & $295.0 \pm 697.7$ & 3.0 & $0.3-108.4$ & 65.8 & 0.7549 \\
\hline DDD & $31.9 \pm 54.4$ & 1.4 & $0.5-38.1$ & 45.6 & $39.2 \pm 96.5$ & 1.2 & $0.7-18.6$ & 39.5 & 0.5156 \\
\hline Dieldrin & $5.1 \pm 18.0$ & 1.1 & $0.4-1.4$ & 13.6 & $21.5 \pm 59.9$ & 0.8 & $0.3-3.1$ & 23.7 & 0.9834 \\
\hline Lindane & - & - & - & 0 & $0.4 \pm 0.9$ & 0.3 & $0.2-0.5$ & 2.6 & 0.4574 \\
\hline Acenaphthene & $0.7 \pm 1.5$ & 0.4 & $0.2-0.6$ & 4.5 & $0.5 \pm 0.3$ & 0.4 & $0.2-0.6$ & 7.9 & 0.9539 \\
\hline Acenaphthylene & - & - & - & 0 & $0.4 \pm 0.3$ & 0.3 & $0.1-0.5$ & 7.9 & 0.1224 \\
\hline Anthracene & $1.0 \pm 2.5$ & 0.5 & $0.1-0.7$ & 4.5 & $0.4 \pm 0.7$ & 0.3 & $0.1-0.6$ & 2.6 & 0.2252 \\
\hline Benzo[a]anthracene & $1.1 \pm 1.7$ & 0.4 & $0.2-0.7$ & 15.9 & $1.8 \pm 4.7$ & 0.4 & $0.1-0.7$ & 13.2 & 0.9318 \\
\hline Benzo[b]fluoranthene & $0.6 \pm 1.5$ & 0.3 & $0.2-0.5$ & 4.5 & $3.9 \pm 12.1$ & 0.4 & $0.2-0.7$ & 7.9 & 0.0975 \\
\hline Chrysene & $0.4 \pm 0.8$ & 0.3 & $0.1-0.6$ & 2.3 & $1.8 \pm 5.3$ & 0.4 & $0.3-0.5$ & 2.6 & 0.0591 \\
\hline Fluoranthene & $4.3 \pm 9.5$ & 0.4 & $0.2-0.7$ & 22.7 & $2.2 \pm 4.9$ & 0.5 & $0.2-0.7$ & 15.8 & 0.7478 \\
\hline Fluorene & $0.7 \pm 1.6$ & 0.4 & $0.2-0.6$ & 4.5 & - & - & - & 0 & 0.8369 \\
\hline Naphthalene & $0.6 \pm 1.0$ & 0.4 & $0.2-0.6$ & 4.5 & - & - & - & 0 & 0.4631 \\
\hline Phenanthrene & $3.8 \pm 11.5$ & 0.6 & $0.3-1.4$ & 27.3 & $1.3 \pm 2.2$ & 0.4 & $0.2-1.3$ & 26.3 & 0.5155 \\
\hline Pyrene & $3.6 \pm 7.4$ & 0.4 & $0.2-1.6$ & 25.0 & $2.2 \pm 5.1$ & 0.4 & $0.2-0.6$ & 15.8 & 0.5740 \\
\hline PCB28 & $0.4 \pm 0.2$ & 0.3 & $0.2-0.6$ & 11.4 & $0.4 \pm 0.2$ & 0.4 & $0.2-0.6$ & 21.1 & 0.9650 \\
\hline PCB52 & $0.5 \pm 0.2$ & 0.5 & $0.3-0.7$ & 4.5 & $0.4 \pm 0.2$ & 0.5 & $0.2-0.6$ & 7.9 & 0.6091 \\
\hline
\end{tabular}

However, the levels of two contaminants ( $\mathrm{p}, \mathrm{p}^{\prime}$-DDE and $\mathrm{p}, \mathrm{p}^{\prime}$-DDD) did attract our attention, not so much because of the frequency of detection, which was similar to that reported in other studies ( $>70 \%$ of the samples), but because of the high concentrations detected. In fact, $\mathrm{p}, \mathrm{p}^{\prime}$-DDE levels in the samples of our series presented mean $\left(364.6 \pm 698.7 \mathrm{ng} \mathrm{g}^{-1}\right)$ and median $\left(58.7 \mathrm{ng} \mathrm{g}^{-1}\right)$ values that are much higher than those reported in other recent studies in Turkey [65], India [66], Poland [67,68], or Iran [69]. In fact, the highest value in our series $\left(2305.6 \mathrm{ng} \mathrm{g}^{-1}\right)$, which paradoxically was found in a farm dedicated to organic vegetable farming, was about twice the median value reported for a region of Azerbaijan that has been reported to be historically contaminated by DDT (and its metabolites), because it was subjected to intensive aerial spraying campaigns [70]. It is still surprising that more than 50 years after the banning of DDT, such high levels of its metabolites are still detected. However, as mentioned before, previous studies have indicated that the level of contamination by this insecticide in the Canary Islands has been very high, because historically there has been very intensive usage of this insecticide in agriculture in this archipelago; even today, this region stands out for its intensive use of pesticides, one of the highest rates in Europe [71].

It was precisely the fact of detecting such a high level of DDE contamination on an organic farm that led us to extend the sampling and make a comparison between 
the two types of production. As shown in Table 4, approximately the same types of residues were detected in some farms as in others, and with similar detection frequencies and concentrations. Thus, we did not find statistically significant differences, either in the individual compounds, or in the sums by chemical group (Figure 4). This lack of differences would reflect the still-high levels of residual contamination in this region.
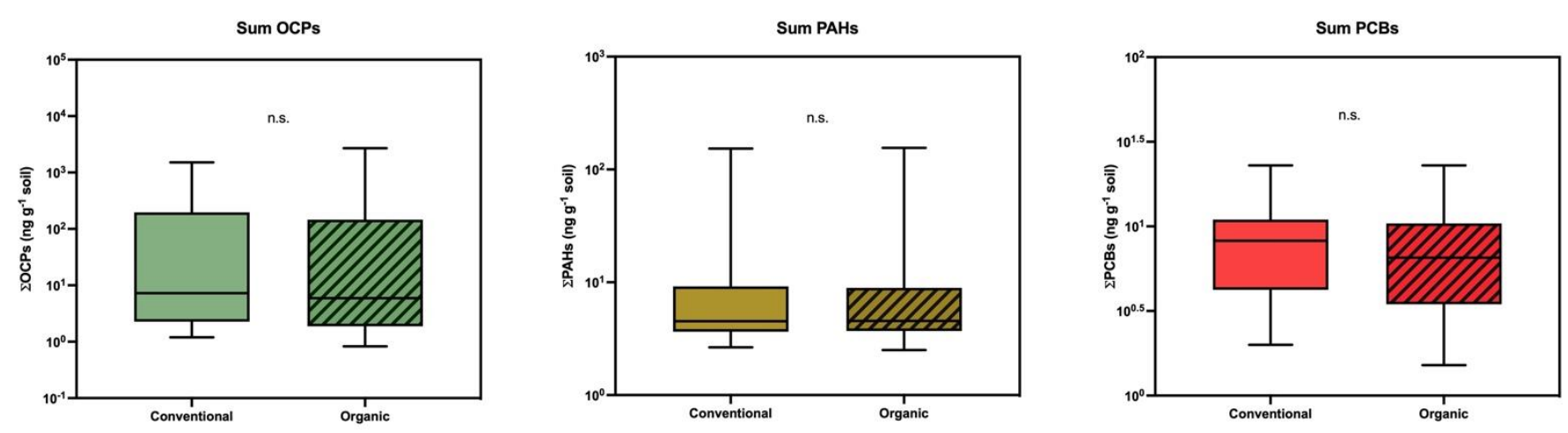

Figure 4. Comparative study of sums of organochlorine pesticides, polycyclic aromatic hydrocarbons, and polychlorinated biphenyls between farms of conventional production and those of organic production. The lines show the medians, the boxes cover the 25 th to 75 th percentiles, and the minimal and maximal values are shown by the ends of the bars.

Finally, we wanted to conduct another comparative study between agricultural soils subjected to a different degree of erosion. The reason lies in the fact that, despite decades since the banning of DDT, gradual declines in its levels were observed in many sites, followed by a second peak of apparent contamination with a new rise in the levels of this insecticide and its metabolites, which could be related to the deposition of new sediments removed from soils subjected to intense erosion [72]. A major cause of agricultural soil erosion is the use of herbicides such as glyphosate and atrazine [72]. In vineyards, the intensive use of herbicides to eliminate weeds between and within vine rows is frequent [73]. This originates from estates with very little vegetation cover, resulting in high soil erosion during rainfall, especially storms, and on hillside estates [74]. Therefore, in this study, we wanted to compare farms dedicated to mixed vegetable crops, with higher vegetation cover and lower herbicide use, with that of vineyards in the Canary Islands. We had not found differences between organic and conventional farms; therefore, we decided not to consider these subgroups. As shown in Table 5 and Figure 5 (summations), we found significant differences in the concentrations of p, $\mathrm{p}^{\prime}-\mathrm{DDE}, \mathrm{p}, \mathrm{p}$-DDD, and dieldrin, although in the opposite directions to those theorized by other authors [72,73]. Our results indicated that the concentration of organochlorines in farms devoted to mixed vegetable cultivation was much higher than that in vineyards, which would present levels very much in line with those reported recently in studies around the world [65-69]. This further highlights the need for robust and reliable analytical tools to routinely monitor levels of persistent and semi-persistent organic pollutants because, as we have seen, levels can vary greatly from place to place. 
Table 5. Comparative study of the POPs detected in 35 samples of agricultural soil of farms devoted to mixed vegetables and fruits and 46 samples from vineyards. Concentrations are expressed in $\mu \mathrm{g} \mathrm{kg}^{-1}$.

\begin{tabular}{|c|c|c|c|c|c|c|c|c|c|}
\hline \multirow[b]{2}{*}{ Compound } & \multicolumn{4}{|c|}{ Conventional Production } & \multicolumn{4}{|c|}{ Organic Production } & \multirow[b]{2}{*}{$p$-Value } \\
\hline & Mean \pm SD & Median & P25-P75 & Freq. (\%) & Mean \pm SD & Median & P25-P75 & Freq. (\%) & \\
\hline DDE & $456.2 \pm 721.6$ & $148.8^{* * * *}$ & $5.8-568.9$ & 91.4 & $58.4 \pm 185.3$ & 0.5 & $0.2-7.9$ & 51.0 & $<0.0001$ \\
\hline DDD & $55.8 \pm 66.5$ & $32.6^{* * *}$ & $0.9-119.0$ & 62.8 & $19.2 \pm 78.8$ & 1.2 & $0.5-2.7$ & 27.7 & 0.0006 \\
\hline Dieldrin & $27.3 \pm 63.8$ & $1.3 *$ & $0.4-5.6$ & 34.3 & $1.8 \pm 5.0$ & 0.8 & $0.5-1.3$ & 6.4 & 0.0240 \\
\hline Lindane & - & - & - & 0 & $0.4 \pm 0.9$ & 0.3 & $0.1-0.5$ & 4.3 & 0.9478 \\
\hline Acenaphthene & $0.9 \pm 1.7$ & 0.5 & $0.3-0.7$ & 14.3 & - & - & - & 0 & 0.0964 \\
\hline Acenaphthylene & $0.5 \pm 0.3$ & 0.4 & $0.3-0.6$ & 8.5 & - & - & - & 0 & 0.3506 \\
\hline Anthracene & $1.1 \pm 2.7$ & 0.4 & $0.2-0.6$ & 5.7 & $0.5 \pm 0.6$ & 0.5 & $0.1-0.7$ & 2.1 & 0.7503 \\
\hline Benzo[a]anthracene & $1.3 \pm 1.8$ & 0.6 & $0.3-1.5$ & 25.7 & $1.5 \pm 4.2$ & 0.5 & $0.2-0.7$ & 8.5 & 0.4825 \\
\hline Benzo[b]fluoranthene & - & - & - & 0 & $3.4 \pm 10.8$ & 0.5 & $0.2-0.7$ & 17.0 & 0.2092 \\
\hline Chrysene & - & - & - & 0 & $1.6 \pm 4.7$ & 0.4 & $0.2-0.6$ & 8.5 & 0.8092 \\
\hline Fluoranthene & $5.7 \pm 10.4$ & 0.6 & $0.3-6.6$ & 31.4 & $1.6 \pm 4.3$ & 0.5 & $0.2-0.7$ & 10.6 & 0.2515 \\
\hline Fluorene & $0.8 \pm 1.8$ & 0.4 & $0.2-0.6$ & 5.7 & - & - & - & 0 & 0.9766 \\
\hline Naphthalene & $0.6 \pm 1.1$ & 0.4 & $0.1-0.6$ & 5.7 & - & - & - & 0 & 0.5803 \\
\hline Phenanthrene & $4.9 \pm 12.8$ & 0.6 & $0.5-4.2$ & 40.0 & $1.0 \pm 1.9$ & 0.5 & $0.3-0.7$ & 17.0 & 0.0315 \\
\hline Pyrene & $4.8 \pm 8.2$ & 0.4 & $0.2-7.6$ & 31.4 & $1.5 \pm 4.3$ & 0.3 & $0.2-0.8$ & 14.9 & 0.1583 \\
\hline PCB28 & - & - & - & 0 & $0.4 \pm 0.3$ & 0.3 & $0.2-0.6$ & 27.7 & 0.4995 \\
\hline PCB52 & $0.4 \pm 0.2$ & 0.4 & $0.1-0.6$ & 14.3 & - & - & - & 0 & 0.6052 \\
\hline
\end{tabular}
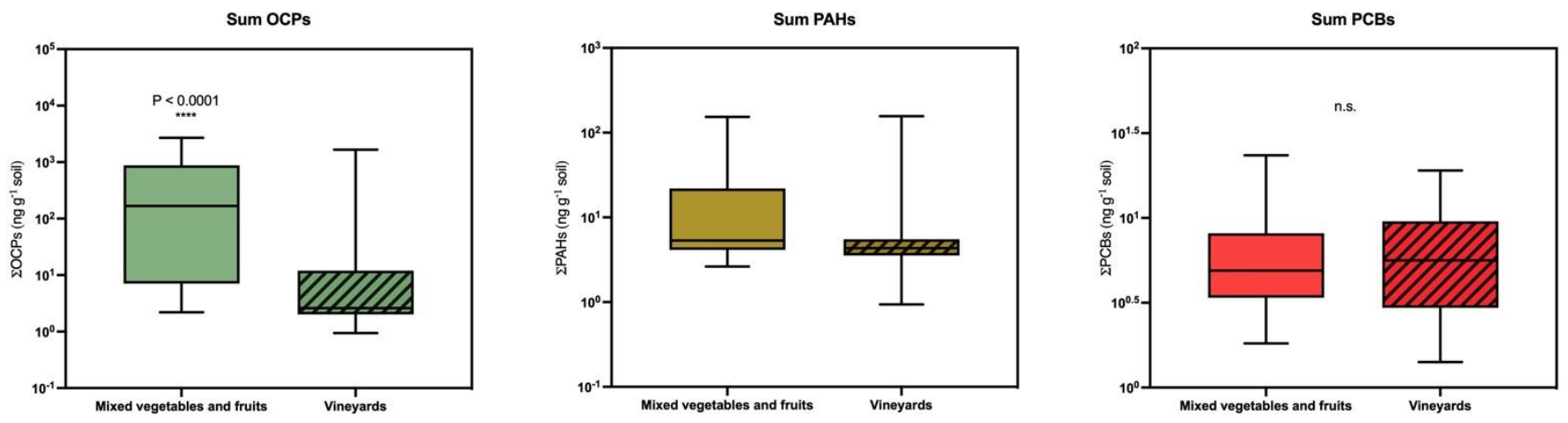

Figure 5. Comparative study of sums of organochlorine pesticides, polycyclic aromatic hydrocarbons, and polychlorinated biphenyls between farms devoted to the production of mixed vegetables and vineyards. The lines show the medians, the boxes cover the 25th to 75th percentiles, and the minimal and maximal values are shown by the ends of the bars.

\section{Conclusions}

In this study, we have successfully validated a one-step QuEChERS-based method without clean-up for the determination of POPs in agricultural soil samples by GC-MS/MS. It has allowed us to simultaneously extract and analyze 49 POPs (8 PBDEs, 12 OCPs, 11 PAHs, and 18 PCBs). We have proven the applicability of this method in a monitoring study of 81 samples collected in plots dedicated to different purposes in the Canary archipelago and to establish the contamination profile by these compounds. In general, we detected very low levels of industrial contaminants, but very high levels of the main DDT metabolites. This is consistent with the high levels of contamination by these pesticides reported in the past in this archipelago. We found no significant differences in contamination levels between conventional and organic farms. However, we did find that the levels of contamination by organochlorine insecticides in the agricultural soils of this region seem to be strongly associated with the type of crop grown on them; levels were significantly higher in farms dedicated to mixed vegetable crops than in vineyards. Further research should shed light on the presence of DDTs and offer bioremediation solutions in most contaminated soils. The method we have validated has proven to be simple, economical, environmentally friendly, and useful for monitoring studies of POPs in soils compared with previously used methods such as Soxhlet, MAE and PLE. 
Author Contributions: Conceptualization, A.A.-D. and O.P.L.; methodology, A.A-.D., C.R.-B., and O.P.L.; software, L.A.H.-H.; validation, A.A.-D., R.D.-D. and M.d.M.B.-S.; formal analysis, A.A.-D., C.R.-B., and M.Z.; investigation, A.A.-D., C.R.-B., M.Z., P.A.-G., and E.P.-D.; resources, O.P.L., and M.Z.; data curation, L.A.H.-H.; writing-original draft preparation, A.A-.D.; writing-review and editing, O.P.L., R.D.-D., M.d.M.B.-S., P.A.-G., and E.P.-D.; visualization, O.P.L.; supervision, O.P.L. and R.D.-D.; project administration, O.P.L.; funding acquisition, O.P.L. All authors have read and agreed to the published version of the manuscript.

Funding: This research was supported by the Spanish Ministry of Education, Culture and Sports, grant number FPU16-01888, to A. Acosta-Dacal, and by the University of Las Palmas de Gran Canaria, grant number ULPGC-012-2016, to C. Rial-Berriel.

Institutional Review Board Statement: Not applicable.

Informed Consent Statement: Not applicable.

Data Availability Statement: The data presented in this study are available on request from the corresponding author.

Acknowledgments: The authors would like to thank Jesús Notario from the Department of Animal Biology, Edaphology and Geology of the University of La Laguna for his help in the identification of the soil samples as clay loam soil, and Ana Macías Montes for her technical assistance in the Toxicology Laboratory of the University of Las Palmas de Gran Canaria.

Conflicts of Interest: The authors declare no conflict of interest.

\section{References}

1. Weber, R.; Bell, L.; Watson, A.; Petrlik, J.; Paun, M.C.; Vijgen, J. Assessment of pops contaminated sites and the need for stringent soil standards for food safety for the protection of human health. Environ. Pollut. 2019, 249, 703-715. [CrossRef]

2. Breivik, K.; Alcock, R.; Li, Y.F.; Bailey, R.E.; Fiedler, H.; Pacyna, J.M. Primary sources of selected POPs: Regional and global scale emission inventories. Environ. Pollut. 2004, 128, 3-16. [CrossRef]

3. Abdel-Shafy, H.I.; Mansour, M.S.M. A review on polycyclic aromatic hydrocarbons: Source, environmental impact, effect on human health and remediation. Egypt J. Pet. 2015. [CrossRef]

4. United Nations Environment Programme. Stockholm Convention. Available online: http://www.pops.int/ (accessed on 9 March 2021).

5. Ministerio de Agricultura y Pesca. Orden de 1 de Febrero de 1991 por la que se Modifica el Anexo de la de 7 de Septiembre de 1989, Sobre Prohibición de la Comercialización y Utilización de Ciertos Productos Fitosanitarios en Aplicación de las Directivas 90/335/CEE y 90/533/CEE. Available online: https:/ / www.boe.es/buscar/doc.php?id=BOE-A-1991-3665 (accessed on 8 March 2021).

6. Ministerio de la Presidencia. Real Decreto 1378 / 1999, de 27 de Agosto, por el que se Establecen Medidas para la Eliminación y Gestión de los Policlorobifenilos, Policloroterfenilos y Aparatos que los Contengan. Available online: https://www.boe.es / buscar/doc.php?id=BOE-A-1999-18193 (accessed on 8 March 2021).

7. Fernandez-Alvarez, M.; Lamas, J.P.; Garcia-Chao, M.; Garcia-Jares, C.; Llompart, M.; Lores, M.; Dagnac, T. Monitoring of pesticide residues in dairy cattle farms from NW Spain. J. Environ. Monit. 2010, 12, 1864. [CrossRef] [PubMed]

8. Mackay, D. Multimedia Environmental Models: The Fugacity Approach; CRC Press: Boca Raton, FL, USA, 2001 ; ISBN 1420032542.

9. Kumari, B.; Madan, V.K.; Kathpal, T.S. Status of insecticide contamination of soil and water in Haryana, India. Monit. Assess. 2008, 136, 239-244. [CrossRef]

10. Tasdemir, Y.; Salihoglu, G.; Salihoglu, N.K.; Birgül, A. Air-soil exchange of PCBs: Seasonal variations in levels and fluxes with influence of equilibrium conditions. Environ. Pollut. 2012, 169, 90-97. [CrossRef]

11. Meijer, S.N.; Ockenden, W.A.; Sweetman, A.; Breivik, K.; Grimalt, J.O.; Jones, K.C. Global distribution and budget of PCBs and HCB in background surface soils: Implications for sources and environmental processes. Environ. Sci. Technol. 2003, 37, 667-672. [CrossRef] [PubMed]

12. Weber, J.B.; Wilkerson, G.G.; Reinhardt, C.F. Calculating pesticide sorption coefficients (Kd) using selected soil properties. Chemosphere 2004, 55, 157-166. [CrossRef]

13. Gevao, B.; Semple, K.T.; Jones, K.C. Bound pesticide residues in soils: A review. Environ. Pollut. 2000, 108, 3-14. [CrossRef]

14. Shen, L.; Wania, F. Compilation, evaluation, and selection of physical-chemical property data for organochlorine pesticides. $J$. Chem. Eng. Data 2005, 50, 742-768. [CrossRef]

15. Connell, D.W.; Miller, G.J.; Mortimer, M.R.; Shaw, G.R.; Anderson, S.M. Persistent lipophilic contaminants and other chemical residues in the southern Hemisphere. Crit. Rev. Environ. Sci. Technol. 1999, 29, 47-82. [CrossRef]

16. Hilber, I.; Mäder, P.; Schulin, R.; Wyss, G.S. Survey of organochlorine pesticides in horticultural soils and there grown Cucurbitaceae. Chemosphere 2008, 73, 954-961. [CrossRef] [PubMed] 
17. Henríquez-Hernández, L.A.; Ortiz-Andrelluchi, A.; Álvarez-Pérez, J.; Acosta-Dacal, A.; Zumbado, M.; Martínez-González, M.A.; Boada, L.D.; Salas-Salvadó, J.; Luzardo, O.P.; Serra-Majem, L. Human biomonitoring of persistent organic pollutants in elderly people from the Canary Islands (Spain): A temporal trend analysis from the predimed and predimed-plus cohorts. Sci. Total Environ. 2021, 758, 143637. [CrossRef] [PubMed]

18. Cabrera-Rodríguez, R.; Luzardo, O.P.; Almeida-González, M.; Boada, L.D.; Zumbado, M.; Acosta-Dacal, A.; Rial-Berriel, C.; Henríquez-Hernández, L.A. Association between prenatal exposure to multiple persistent organochlorine pollutants (POPs) and growth indicators in newborns. Environ. Res. 2018, 171, 285-292. [CrossRef]

19. Ozkoc, H.B.; Bakan, G.; Ariman, S. Distribution and bioaccumulation of organochlorine pesticides along the Black Sea coast. Environ. Geochem. Health 2007, 29, 59-68. [CrossRef] [PubMed]

20. Lanfranchi, A.L.; Menone, M.L.; Miglioranza, K.S.B.; Janiot, L.J.; Aizpún, J.E.; Moreno, V.J. Striped weakfish (cynoscion guatucupa): A biomonitor of organochlorine pesticides in estuarine and near-coastal zones. Mar. Pollut. Bull. 2006, 52, 74-80. [CrossRef] [PubMed]

21. Brevik, E.C.; Burgess, L.C. Soils and Human Health; CRC Press: Boca Raton, FL, USA, 2012; ISBN 9781439844557.

22. Davis, S.; Mirick, D.K. Soil ingestion in children and adults in the same family. J. Expo. Sci. Environ. Epidemiol. 2006, 16, 63-75. [CrossRef] [PubMed]

23. von Lindern, I.; Spalinger, S.; Stifelman, M.L.; Stanek, L.W.; Bartrem, C. Estimating children's soil/dust ingestion rates through retrospective analyses of blood lead biomonitoring from the Bunker Hill superfund site in Idaho. Environ. Health Perspect. 2016, 124, 1462-1470. [CrossRef]

24. Rychen, G.; Jurjanz, S.; Fournier, A.; Toussaint, H.; Feidt, C. Exposure of ruminants to persistent organic pollutants and potential of decontamination. Env. Sci Pollut Res. Int 2014, 21, 6440-6447. [CrossRef]

25. Wong, F.; Alegria, H.A.; Bidleman, T.F. Organochlorine pesticides in soils of Mexico and the potential for soil-air exchange. Environ. Pollut. 2010, 158, 749-755. [CrossRef]

26. Zhou, Q.; Wang, J.; Meng, B.; Cheng, J.; Lin, G.; Chen, J.; Zheng, D.; Yu, Y. Distribution and sources of organochlorine pesticides in agricultural soils from central China. Ecotoxicol. Environ. Saf. 2013, 93, 163-170. [CrossRef] [PubMed]

27. Bianco, G.; Novario, G.; Bochicchio, D.; Anzilotta, G.; Palma, A.; Cataldi, T.R.I. Polychlorinated biphenyls in contaminated soil samples evaluated by GC-ECD with dual-column and GC-HRMS. Chemosphere 2008, 73, 104-112. [CrossRef] [PubMed]

28. During, R.A.; Gäth, S. Microwave assisted methodology for the determination of organic pollutants in organic municipal wastes and soils: Extraction of polychlorinated biphenyls using heat transformer disks. Fresenius. J. Anal. Chem. 2000, 368, 697-701. [CrossRef] [PubMed]

29. Abou-Elwafa Abdallah, M.; Drage, D.; Harrad, S. A one-step extraction/clean-up method for determination of PCBs, PBDEs and HBCDs in environmental solid matrices. Environ. Sci. Process. Impacts 2013, 15, 2279-2287. [CrossRef] [PubMed]

30. Park, H.M.; Hong, S.M.; Agustin-Camacho, M.R.; Dirwono, W.; Lee, K.B. Pressurized liquid extraction for the simultaneous analysis of polychlorinated biphenyls and polybrominated diphenyl ethers from soil by GC-TOF-MS detection. J. Chromatogr. Sci. 2009, 47, 681-688. [CrossRef]

31. He, Z.; Wang, L.; Peng, Y.; Luo, M.; Wang, W.; Liu, X. Determination of selected polychlorinated biphenyls in soil and earthworm (Eisenia fetida) using a QuEChERS-based method and gas chromatography with tandem MS. J. Sep. Sci. 2015, 38, 3766-3773. [CrossRef]

32. Varca, J.P.R.O.; Martins, E.A.J.; Varca, G.H.C.; Romano, R.L.; Lebre, D.T.; Lainetti, P.E.O.; Bustillos, J.O.V. Determination of organochlorines in soil of a suburban area of São Paulo Brazil. Int. J. Environ. Res. Public Health 2020, 17, 5666. [CrossRef]

33. Anastassiades, M.; Lehotay, S.J.; Štajnbaher, D.; Schenck, F.J. Fast and easy multiresidue method employing acetonitrile extraction/partitioning and "dispersive solid-phase extraction" for the determination of pesticide residues in produce. J. AOAC Int. 2003, 86, 412-431. [CrossRef] [PubMed]

34. Perestrelo, R.; Silva, P.; Porto-Figueira, P.; Pereira, J.A.M.; Silva, C.; Medina, S.; Câmara, J.S. QuEChERS-Fundamentals, relevant improvements, applications and future trends. Anal. Chim. Acta 2019, 1070, 1-28. [CrossRef]

35. Correia-Sá, L.; Fernandes, V.C.; Carvalho, M.; Calhau, C.; Domingues, V.M.F.; Delerue-Matos, C. Optimization of QuEChERS method for the analysis of organochlorine pesticides in soils with diverse organic matter. J. Sep. Sci. 2012, 35, 1521-1530. [CrossRef]

36. Xu, X.; Yang, H.; Li, Q.; Yang, B.; Wang, X.; Lee, F.S.C. Residues of organochlorine pesticides in near shore waters of LaiZhou Bay and JiaoZhou Bay, Shandong Peninsula, China. Chemosphere 2007, 68, 126-139. [CrossRef] [PubMed]

37. Ali, M.; Kazmi, A.A.; Ahmed, N. Study on effects of temperature, moisture and $\mathrm{pH}$ in degradation and degradation kinetics of aldrin, endosulfan, lindane pesticides during full-scale continuous rotary drum composting. Chemosphere 2014, 102, 68-75. [CrossRef] [PubMed]

38. Rial-Berriel, C.; Acosta-Dacal, A.; Zumbado, M.; Luzardo, O.P. Micro QuEChERS-based method for the simultaneous biomonitoring in whole blood of 360 toxicologically relevant pollutants for wildlife. Sci. Total Environ. 2020. [CrossRef] [PubMed]

39. Olisah, C.; Okoh, O.O.; Okoh, A.I. Occurrence of organochlorine pesticide residues in biological and environmental matrices in Africa: A two-decade review. Heliyon 2020, 6, e03518. [CrossRef] [PubMed]

40. Zumbado, M.; Goethals, M.; Álvarez-León, E.E.; Luzardo, O.P.; Cabrera, F.; Serra-Majem, L.; Domínguez-Boada, L. Inadvertent exposure to organochlorine pesticides DDT and derivatives in people from the Canary Islands (Spain). Sci. Total Environ. 2005, 339, 49-62. [CrossRef] [PubMed] 
41. Luzardo, O.P.; Goethals, M.; Zumbado, M.; Álvarez-León, E.E.; Cabrera, F.; Serra-Majem, L.; Boada, L.D. Increasing serum levels of non-DDT-derivative organochlorine pesticides in the younger population of the Canary Islands (Spain). Sci. Total Environ. 2006, 367, 129-138. [CrossRef]

42. Boada, L.D.; Henriquez-Hernandez, L.A.; Navarro, P.; Zumbado, M.; Almeida-Gonzalez, M.; Camacho, M.; Alvarez-Leon, E.E.; Valencia-Santana, J.A.; Luzardo, O.P. Exposure to polycyclic aromatic hydrocarbons (PAHs) and bladder cancer: Evaluation from a gene-environment perspective in a hospital-based case-control study in the Canary Islands (Spain). Int J. Occup Environ. Health 2015, 21, 23-30. [CrossRef]

43. Zumbado, M.; Luzardo, O.P.; Lara, P.C.; Alvarez-Leon, E.E.; Losada, A.; Apolinario, R.; Serra-Majem, L.; Boada, L.D. Insulin-like growth factor-I (IGF-I) serum concentrations in healthy children and adolescents: Relationship to level of contamination by DDT-derivative pesticides. Growth Horm IGF Res. 2010, 20, 63-67. [CrossRef]

44. Garcia-Alvarez, N.; Martin, V.; Fernandez, A.; Almunia, J.; Xuriach, A.; Arbelo, M.; Tejedor, M.; Boada, L.D.; Zumbado, M.; Luzardo, O.P. Levels and profiles of POPs (organochlorine pesticides, PCBs, and PAHs) in free-ranging common bottlenose dolphins of the Canary Islands, Spain. Sci. Total Environ. 2014, 493, 22-31. [CrossRef] [PubMed]

45. Luzardo, O.P.; Ruiz-Suarez, N.; Henriquez-Hernandez, L.A.; Valeron, P.F.; Camacho, M.; Zumbado, M.; Boada, L.D. Assessment of the exposure to organochlorine pesticides, PCBs and PAHs in six species of predatory birds of the Canary Islands, Spain. Sci. Total Environ. 2014, 472, 146-153. [CrossRef]

46. Acosta-Dacal, A.; Rial-Berriel, C.; Díaz-Díaz, R.; del Suárez, M.M.B.; Zumbado, M.; Henríquez-Hernández, L.A.; Luzardo, O.P. Supporting dataset on the optimization and validation of a QuEChERS-based method for the determination of 218 pesticide residues in clay loam soil. Data Br. 2020, 33, 106393. [CrossRef] [PubMed]

47. Acosta-Dacal, A.; Rial-Berriel, C.; Díaz-Díaz, R.; del MarBernal-Suárezb, M.; Luzardo, O.P. Optimization and validation of a QuEChERS-based method for the simultaneous environmental monitoring of 218 pesticide residues in clay loam soil. Sci. Total Environ. 2021, 753, 142015. [CrossRef]

48. Hoff, R.B.; Barreto, F.; Melo, J.; Martins, M.T.; Pizzolato, T.M.; Peralba, M.D.C.R. Scope extension validation protocol: Inclusion of analytes and matrices in an LC-MS/MS sulfonamide residues method. Food Addit. Contam.Part. A Chem. Anal. Control. Expo. Risk Assess. 2014, 31, 39-47. [CrossRef] [PubMed]

49. European Commission. Guidance document on analytical quality control and method validation procedures for pesticides residues analysis in food and feed. European Commission Health and Consumer Protection Directorate: Brussel, Belgium, 2019; pp. $2-44$.

50. Lehotay, S.J.; O’Neil, M.; Tully, J.; García, A.V.; Contreras, M.; Mol, H.; Heinke, V.; Anspach, T.; Lach, G.; Fussell, R.; et al. Determination of pesticide residues in foods by acetonitrile extraction and partitioning with magnesium sulfate: Collaborative study. J. AOAC Int. 2007, 90, 485-520. [CrossRef] [PubMed]

51. European Commission. Guidance document on pesticide residue analytical methods; European Commission Directorate General Health and Consumer Protection: Parma, Italy, 2010; p. 34.

52. Wenzl, T.; Haedrich, J.; Schaechtele, A.; Robouch, P.; Stroka, J. Guidance Document on the Estimation of LOD and LOQ for Measurements in the Field of Contaminants in Feed and Food; Publications Office of the European Union: Luxembourg, 2016.

53. Maštovská, K.; Lehotay, S.J. Evaluation of common organic solvents for gas chromatographic analysis and stability of multiclass pesticide residues. J. Chromatogr. A 2004, 1040, 259-272. [CrossRef]

54. Asensio-Ramos, M.; Hernández-Borges, J.; Ravelo-Pérez, L.M.; Rodríguez-Delgado, M.A. Evaluation of a modified QuEChERS method for the extraction of pesticides from agricultural, ornamental and forestal soils. Anal. Bioanal. Chem. 2010, 396, 2307-2319. [CrossRef] [PubMed]

55. Fernandes, V.C.; Domingues, V.F.; Mateus, N.; Delerue-Matos, C. Multiresidue pesticides analysis in soils using modified QuEChERS with disposable pipette extraction and dispersive solid-phase extraction. J. Sep. Sci. 2013, 36, 376-382. [CrossRef]

56. Jiao, X.; Tang, Q.; Chen, S.; Deng, Y.; Cao, H.; Wang, G.; Yang, Y. Spatial distribution and temporal trends of farmland soil PBDEs: Processes and crop rotation effects. Environ. Sci. Pollut. Res. 2016, 23, 13137-13146. [CrossRef]

57. Gaylor, M.O.; Mears, G.L.; Harvey, E.; La Guardia, M.J.; Hale, R.C. Polybrominated diphenyl ether accumulation in an agricultural soil ecosystem receiving wastewater sludge amendments. Environ. Sci. Technol. 2014, 48, 7034-7043. [CrossRef]

58. Xu, J.; Qian, W.; Li, J.; Zhang, X.; He, J.; Kong, D. Polybrominated diphenyl ethers (PBDEs) in soil and dust from plastic production and surrounding areas in eastern of China. Environ. Geochem. Health 2019, 41, 2315-2327. [CrossRef]

59. Camacho, M.; Herrera, A.; Gómez, M.; Acosta-Dacal, A.; Martínez, I.; Henríquez-Hernández, L.A.; Luzardo, O.P. Organic pollutants in marine plastic debris from Canary Islands beaches. Sci. Total Environ. 2019, 662. [CrossRef]

60. Henríquez-Hernández, L.A.; Luzardo, O.P.; Arellano, J.L.P.; Carranza, C.; Sánchez, N.J.; Almeida-González, M.; Ruiz-Suárez, N.; Valerón, P.F.; Camacho, M.; Zumbado, M.; et al. Different pattern of contamination by legacy POPs in two populations from the same geographical area but with completely different lifestyles: Canary Islands (Spain) vs. Morocco. Sci. Total Environ. 2016, 541, 51-57. [CrossRef] [PubMed]

61. Turrio-Baldassarri, L.; Abate, V.; Alivernini, S.; Battistelli, C.L.; Carasi, S.; Casella, M.; Iacovella, N.; Iamiceli, A.L.; Indelicato, A.; Scarcella, C.; et al. A study on PCB, PCDD/PCDF industrial contamination in a mixed urban-agricultural area significantly affecting the food chain and the human exposure. Part I: Soil and feed. Chemosphere 2007, 67, 1822-1830. [CrossRef] [PubMed]

62. Hanedar, A.; Güneş, E.; Kaykioğlu, G. Presence and distributions of POPS in soil, atmospheric deposition, and bioindicator samples in an industrial-agricultural area in Turkey. Environ. Monit. Assess. 2019, 191, 42. [CrossRef] [PubMed] 
63. Mackiewicz-Walec, E.; Krzebietke, S.J. Content of polycyclic aromatic hydrocarbons in soil in a multi-annual fertilisation regime. Environ. Monit. Assess. 2020, 192. [CrossRef] [PubMed]

64. Cai, Q.Y.; Mo, C.H.; Wu, Q.T.; Katsoyiannis, A.; Zeng, Q.Y. The status of soil contamination by semivolatile organic chemicals (SVOCs) in China: A review. Sci. Total Environ. 2008, 389, 209-224. [CrossRef] [PubMed]

65. Akça, M.O.; Hisatomi, S.; Takemura, M.; Harada, N.; Nonaka, M.; Sakakibara, F.; Takagi, K.; Turgay, O.C. 4,4'-DDE and endosulfan levels in agricultural soils of the çukurova region, Mediterranean Turkey. Bull. Environ. Contam. Toxicol. 2016, 96, 376-382. [CrossRef]

66. Khuman, S.N.; Vinod, P.G.; Bharat, G.; Kumar, Y.S.M.; Chakraborty, P. Spatial distribution and compositional profiles of organochlorine pesticides in the surface soil from the agricultural, coastal and backwater transects along the south-west coast of India. Chemosphere 2020, 254, 126699. [CrossRef]

67. Ukalska-Jaruga, A.; Smreczak, B.; Siebielec, G. Assessment of pesticide residue content in Polish agricultural soils. Molecules 2020, 25, 587. [CrossRef]

68. Malusá, E.; Tartanus, M.; Danelski, W.; Miszczak, A.; Szustakowska, E.; Kicińska, J.; Furmanczyk, E.M. Monitoring of DDT in agricultural soils under organic farming in Poland and the risk of crop contamination. Environ. Manag. 2020, 66, 916-929. [CrossRef]

69. Kafaei, R.; Arfaeinia, H.; Savari, A.; Mahmoodi, M.; Rezaei, M.; Rayani, M.; Sorial, G.A.; Fattahi, N.; Ramavandi, B. Organochlorine pesticides contamination in agricultural soils of southern Iran. Chemosphere 2020, 240. [CrossRef] [PubMed]

70. Ukalska-Jaruga, A.; Lewí nska, K.; Mammadov, E.; Karczewska, A.; Smreczak, Z.; Medy, A. Molecules Residues of persistent organic pollutants (POPs) in agricultural soils adjacent to historical sources of their storage and distribution-the case study of Azerbaijan. Molecules 2020, 25, 1815. [CrossRef]

71. Alonso González, P.; Parga-Dans, E.; Pérez Luzardo, O. Big sales, no carrots: Assessment of pesticide policy in Spain. Crop. Prot. 2021, 141, 105428. [CrossRef]

72. Sabatier, P.; Poulenard, J.; Fanget, B.; Reyss, J.-L.; Develle, A.-L.; Wilhelm, B.; Ployon, E.; Pignol, C.; Naffrechoux, E.; Dorioz, J.-M.; et al. Long-term relationships among pesticide applications, mobility, and soil erosion in a vineyard watershed. Proc. Natl. Acad. Sci. USA 2014, 111, 15647-15652. [CrossRef]

73. Zaller, J.G.; Cantelmo, C.; Dos Santos, G.; Muther, S.; Gruber, E.; Pallua, P.; Mandl, K.; Friedrich, B.; Hofstetter, I.; Schmuckenschlager, B.; et al. Herbicides in vineyards reduce grapevine root mycorrhization and alter soil microorganisms and the nutrient composition in grapevine roots, leaves, xylem sap and grape juice. Environ. Sci. Pollut. Res. 2018, 25, 23215-23226. [CrossRef] [PubMed]

74. Patinha, C.; Durães, N.; Dias, A.C.; Pato, P.; Fonseca, R.; Janeiro, A.; Barriga, F.; Reis, A.P.; Duarte, A.; Ferreira da Silva, E.; et al. Long-term application of the organic and inorganic pesticides in vineyards: Environmental record of past use. Appl. Geochem. 2018, 88, 226-238. [CrossRef] 